\title{
Michael Addition Reaction Catalyzed by Imidazolium Chloride to Protect Amino Groups and Construct Medium Ring Heterocycles
}

\author{
Zeshu Dai $^{\dagger}$, Qingqiang Tian ${ }^{\dagger}$, Yanwu Li, Suqin Shang, Wen Luo, Xuetong Wang, Dan Li, \\ Ying Zhang, Zhiyao Li and Jianyong Yuan* \\ Department of Medicinal Chemistry, College of Pharmacy, Chongqing Medical University, Chongqing 400016, \\ China; daizs11@163.com (Z.D.); Tqingqiang@163.com (Q.T.); lyanwu@163.com (Y.L.); ssqhcq@163.com (S.S.); \\ Lwen1129@163.com (W.L.); wxy998298@163.com (X.W.); 1d28115@163.com (D.L.); \\ yingzhang0728@163.com (Y.Z.); 18883850724@163.com (Z.L.) \\ * Correspondence: 102542@cqmu.edu.cn \\ † These authors contributed equally to this work.
}

Received: 26 September 2019; Accepted: 30 October 2019; Published: 20 November 2019

\begin{abstract}
An effective approach for amino protection and construction of a seven-membered ring has been developed. The method uses imidazolium chloride to carry out the Michael addition reaction at low temperatures and perform amino deprotection or construction of a seven-membered ring at high temperatures.
\end{abstract}

Keywords: imidazolium chloride; amino protection; Michael addition reaction; amino deprotection; solvent-free; seven-membered ring

\section{Introduction}

Many pharmaceutical intermediates or active molecules often contain amino groups. However, the amino groups are unstable and easily oxidized. The protection of amino groups is therefore often needed in the process of drug synthesis. Methods of amino functional group protection have been reported by related literatures or patents [1]. Traditionally, functional groups were protected via amines reacting with CBZ-Cl [2,3], (Boc) ${ }_{2} \mathrm{O}[4-6]$, Fmoc-Cl [7], TFA [8,9] and Alloc-Cl [10] in the presence of inorganic bases. Furthermore, we have found that bases are mainly used as a promoter. Recently, Jadhav et al. [11] reported the use of microwaves $(300 \mathrm{~W})$ for selective tert-butoxycarbonylation of various amines. In 2015, Liguori et al. [12] reported the use of 1-butyl-3-methylimidazolium tetrauoroborate [Bmim] $\left[\mathrm{BF}_{4}\right]$ as the ionic liquid medium to promote selective Fmoc and Cbz-protection of various structurally amines. Among the relevant protective groups used for amino function, it would also be necessary to mention the sulfonamido $[13,14]$ protecting groups. Several protocols have been developed for the protection of amino groups with substituted sulfonyl chlorides (such as 4-toluolsulfonyl chloride) using various metal-based catalyst reaction conditions. In 2013, Nardi et al. [15] reported a new and eco-friendly process for ferrier glycosylation of sulfonamides and amino acids with various $\mathrm{N}$-nucleophiles under erbium (III) trifluoromethane-sulfonate as a Lewis acid catalyst. However, these catalysts present a lot of disadvantages. Most of these reactions have limitations such as high cost, corrosiveness, and toxicity. Although methods for the protection of various amino groups are well known and well documented in the literature, it is still very important to study the methods of protecting amino groups. Furthermore, in recent years, a number of researchers have focused on developing greener methods.

When we began to study the reaction of o-phenylenediamine with $N, N$-dimethylacrylamide catalyzed by imidazolium chloride to construct a seven-membered ring [16-18], we found that the 
reactants reacted in the form of Michael addition $[19,20]$ reaction at $120^{\circ} \mathrm{C}$, firstly. However, when the temperature was raised to $150^{\circ} \mathrm{C}$, the reaction product did not contain any seven-membered ring. After identification, it was one of the raw materials that was formed by the $\mathrm{C}-\mathrm{N}$ bond cleavaging. In the next study, we find that reaction of o-phenylenediamine with acrylamide in the presence of imidazole hydrochloride resulted in the formation of 1,3,4,5-tetrahydro-2H-benzo[b][1,4]diazepin-2-one. In 2012, Dabiri, M. et al. [21] reported that [Hmim]TFA catalyzed the hetero-Michael reaction of 2 -aminothiophenol and acrylate to construct a seven-membered ring. However, this method only provided a ring-closing reaction of 2-aminothiophenol and acrylate, but the ring-closing reaction of substituted phenylenediamine and a variety of Michael acceptors is still not clear.

Michael addition was one of the most important carbon-carbon and carbon-heteroatom bond-forming strategies in synthetic organic chemistry. In the past few years, a myriad array of metal-centered Lewis acid catalysts have been developed, including cadmium (II) chloride [22], ammonium nitrate(V) [23], zirconium(IV) chloride [24], silica-supported aluminum chloride [25], $\mathrm{VO}(\mathrm{OTf})_{2}$ [26] and lanthanum trichloride $\left(\mathrm{LaCl}_{3}\right)$ [27]. Recently, green organic chemistry has begun to attract attention in organic synthesis. For example, metal organic frameworks [28] and basic alumina [29]. Although these reactions work well, most of these catalysts were non-recyclable or transition metal salt catalysts. In addition, in some cases, toxic solvents were required, and a long reaction time was needed. Therefore, it was necessary to explore non-metallic catalysts in organic synthesis. We recently reported an environmentally-friendly procedure to efficiently obtain Aza-Michael adducts using imidazolium chloride as a green catalyst.

Based on these results, we propose using imidazolium hydrochloride to catalyze the Michael addition reaction to protect amino groups and synthesize benzodiazepine derivatives and benzothiazide derivatives. (Scheme 1).

(a)

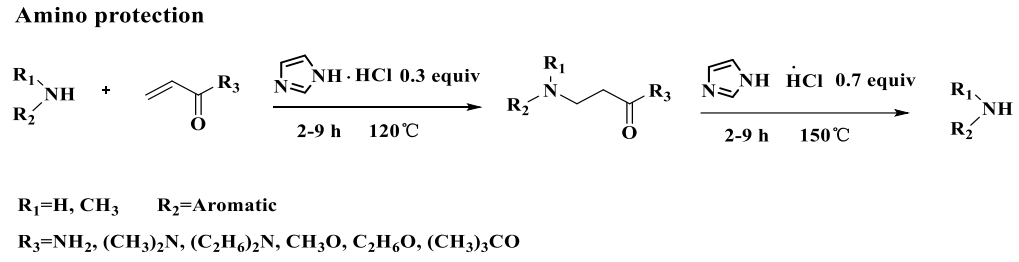

(b) Synthesis of benzodiazepine derivatives and benzothiazepine derivatives

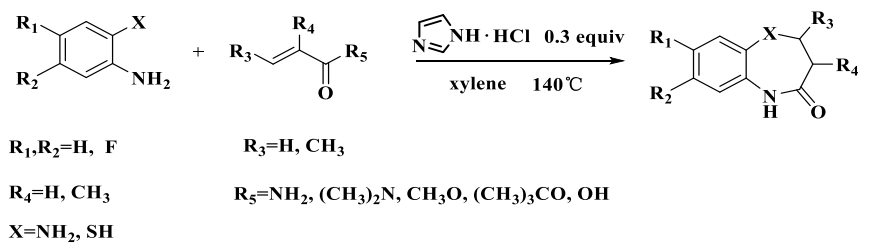

Scheme 1. Amino protection catalyzed by imidazole hydrochloride.

\section{Results and Discussion}

\subsection{Optimization of Reaction Conditions}

In our initial experiments, we choose aniline with $N, N$-dimethylacrylamide as a model substrate and the results for development are displayed in Table 1. 
Table 1. Optimization of conditions for the reaction of the Aza-Michael addition.

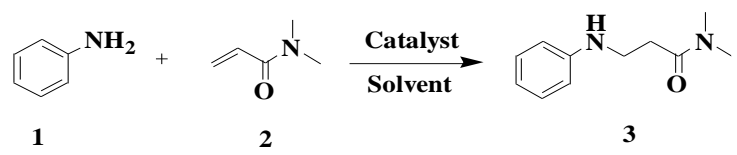

\begin{tabular}{|c|c|c|c|c|c|}
\hline Entry & Cat (eq) & Solvent & Temperature $\left({ }^{\circ} \mathrm{C}\right)$ & Time (h) & Yield $(\%)^{c}$ \\
\hline 1 & - & - & 120 & 4 & trace \\
\hline 2 & Imidazolium chloride (0.3) & - & 120 & 4 & 69 \\
\hline 3 & Imidazole $(0.3)$ & - & 120 & 6 & 10 \\
\hline 4 & $\mathrm{HCl}(0.3)$ & - & 120 & 4 & 60 \\
\hline 5 & Imidazolium chloride (0.3) & - & 90 & 6 & 50 \\
\hline 6 & Imidazolium chloride (0.3) & - & 120 & 4 & 75 \\
\hline 7 & Imidazolium chloride (0.3) & - & 130 & 4 & 65 \\
\hline 8 & Imidazolium chloride (0.3) & - & 140 & 4 & 40 \\
\hline 9 & Imidazolium chloride (0.1) & - & 120 & 4 & 32 \\
\hline 10 & Imidazolium chloride $(0.2)$ & - & 120 & 4 & 61 \\
\hline 11 & Imidazolium chloride (0.5) & - & 120 & 4 & 73 \\
\hline $12^{b}$ & Imidazolium chloride (0.3) & $\mathrm{H}_{2} \mathrm{O}$ & 100 & 6 & 18 \\
\hline $13^{b}$ & Imidazolium chloride (0.3) & $\mathrm{CH}_{3} \mathrm{CN}$ & 70 & 6 & $\mathrm{NO}$ \\
\hline $14^{\mathrm{b}}$ & Imidazolium chloride (0.3) & Toluene & 120 & 4 & 63 \\
\hline $15^{b}$ & Imidazolium chloride (0.3) & Xylene & 120 & 4 & 66 \\
\hline
\end{tabular}

a Reaction conditions: Unless otherwise noted, all reactions were carried out with 1 (10.8 mmol, 1 equiv), 2 (14.0 mmol, 1.3 equiv), Imidazolium chloride ( $0.1-0.5$ equiv); ${ }^{b}$ All solvents are $2 \mathrm{~mL} ;{ }^{c}$ Yields of products 3 . Abbreviations: $\mathrm{NO}$, no reaction.

Firstly, our investigation commenced with the reaction of aniline 1 and $N, N$-dimethyl acrylamide 2 with imidazolium chloride $\left(0.3\right.$ equiv) at $110^{\circ} \mathrm{C}$ solvent-free. We obtained product 3 (Table 1, Entry 2$)$ in a yield of $69 \%$. However, only a trace product was detected in the absence of catalysts (Table 1, Entry 1). On the other hand, when we used 0.3 equiv of $\mathrm{HCl}$ and imidazole as catalysts, we obtained products 3 and 4 (Table 1, Entries 3 and 4) in yields of $60 \%$ and 10\%, respectively. Inspired by the results, the impact of varying the reaction temperature was investigated (Table 1, Entries 5-8). The best yield was obtained under solvent-free conditions at $120^{\circ} \mathrm{C}$ (Table 1, Entry 6). When the temperature was raised or decreased, the yields lowered (Table 1, Entries 5, 7 and 8). These experiments demonstrated that the reaction was highly sensitive to temperature. Next, concerning the amount of catalysts, it was observed that 0.3 eq of imidazolium chloride were sufficient to obtain a good yield. Lowering the amount of catalyst from $30 \mathrm{~mol} \%$ to $10 \mathrm{~mol} \%$ resulted in a yield of $32 \%$, indicating that the yields were significantly decreased (Table 1, Entries 9 and 10). Increasing the amount of catalysts had little influence on the yield (Table 1, Entry 11). Finally, we turn our target to the effect of solvents on the reaction. We had tried various solvents such as water and acetonitrile, but unsatisfactory yields were obtained, possibly a result from the effect of temperature on the reaction (Table 1, Entries 12 and 13). However, the reaction was attempted in non-polar media such as toluene and xylene, and a total yield of $63 \%-66 \%$ was obtained (Table 1, Entries 14 and 15 ).

Interestingly, our team unexpectedly discovered that imidazolium chloride could catalyze the $\mathrm{C}-\mathrm{N}$ bond-cleavaging reactions at $150^{\circ} \mathrm{C}$. So, after the amino group was protected, we began to screen the conditions for amino deprotection. The $N, N$-Dimethyl-3-phenylamino-propionamide (Tables 2 and 3,3 ) was selected as the model reaction for $6 \mathrm{~h}$. The results are listed in Table 2. 
Table 2. Optimization of reaction conditions for the deprotection of amino group a

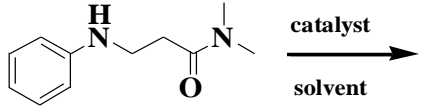

3

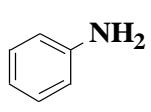

\begin{tabular}{cccccc}
\hline Entry & Cat (eq) & Solvent & Temperature $\left({ }^{\circ} \mathbf{C}\right)$ & Time (h) & Yield (\%) $)^{\mathbf{b}}$ \\
\hline 1 & - & - & 150 & 6 & Trace \\
2 & Imidazole (0.7) & - & 150 & 6 & Trace \\
3 & $\mathrm{HCl} \mathrm{(0.7)}$ & - & 150 & 6 & 8 \\
4 & Imidazolium chloride (0.7) & - & 120 & 6 & Trace \\
5 & Imidazolium chloride (0.7) & - & 150 & 6 & 61 \\
6 & Imidazolium chloride (0.7) & - & 160 & 6 & 63 \\
7 & Imidazolium chloride (0.7) & - & 180 & 6 & 65 \\
8 & Imidazolium chloride (0.1) & - & 150 & 6 & 23 \\
9 & Imidazolium chloride (0.5) & - & 150 & 6 & 35 \\
10 & Imidazolium chloride (1.0) & - & 150 & 6 & 65 \\
$11^{\mathrm{c}}$ & Imidazolium chloride (0.7) & $\mathrm{H}_{2} \mathrm{O}$ & 100 & 6 & NO \\
$12^{\mathrm{c}}$ & Imidazolium chloride (0.7) & benzene & 90 & 6 & NO \\
$13^{\mathrm{c}}$ & Imidazolium chloride (0.7) & xylene & 150 & 6 & 57 \\
\hline
\end{tabular}

a General conditions: 3 (5.2 mmol, 1 equiv), imidazolium chloride (0.1-1 equiv) under solvent-free conditions for 6 $\mathrm{h} ;{ }^{\mathrm{b}}$ Isolated yields are given; ${ }^{\mathrm{c}}$ All solvents are $2 \mathrm{~mL}$. Abbreviations: NO, no reaction.

At the beginning of our study, we found that the reaction was performed under the conditions of 0.7 equivalent of imidazolium chloride at $150^{\circ} \mathrm{C}$. The expected product was detected (Table 2, Entry 5). However, only a trace product was detected in the absence of catalysts (Table 2, Entry 1). When 0.7 equiv of $\mathrm{HCl}$ was used, the yield of the product 1 (Table 2, Entry 3) was $8 \%$. Furthermore, the impact of varying the reaction temperature was investigated. Compared to the yield of 1 at $150{ }^{\circ} \mathrm{C}$ (Table 2, entry 5), the yield of the reaction performed at $120^{\circ} \mathrm{C}$ was significantly decreased (Table 2, Entry 4). However, when temperature was increased to $160{ }^{\circ} \mathrm{C}$ and $180^{\circ} \mathrm{C}$ for $6 \mathrm{~h}$, the yields were $63 \%$ and $65 \%$, respectively (Table 2, Entries 6 and 7). The expected product was obtained at a yield of $23 \%$ only when the amount of catalyst was decreased to $10 \mathrm{~mol} \%$ (Table 2, Entry 8 ). The yield of product 1 did not increase significantly when the reaction was carried out at the condition of 1 equiv of catalyst (Table 2, Entry 10) compared to 0.7 equiv of catalyst (Table 2, Entries 5). When the reaction was performed in water or benzene, no reaction occurred in the presence of catalyst (Table 2, Entries 11 and 12). The yield of the expected product was $57 \%$ when the reaction was conducted in xylene (Table 2, Entry 13). The optimum yield was obtained when the reaction was carried out under solvent free conditions (Table 2, Entry 5).

However, the reaction of o-phenylenediamine with acrylamide at $140{ }^{\circ} \mathrm{C}$ for $5 \mathrm{~h}$ to obtain 1,3,4,5-tetrahydro-2H-ben-zo[b][1,4]diazepin-2-one gave a very good yield. Inspired by this result, we herein tried to synthesize benzodiazepines and benzothiazides derivatives through the further study of Michael addition reaction. Hence, the o-phenylenediamine (4) and acrylamide (5) were selected as the substrates for the optimization studies. Gratifyingly, the substrates $\mathbf{4}$ and $\mathbf{5}$ could be transformed into product 6 in a yield of $45 \%$ by heating in the presence of imidazole hydrochloride in xylene at $140{ }^{\circ} \mathrm{C}$ for $5 \mathrm{~h}$ (Table 3, Entry 1). Next, a variety of temperatures were explored; it was observed that the desired yields can be obtained only at $140^{\circ} \mathrm{C}$ (Table 3, Entries 5-9). Subsequently, several other solvents such as $\mathrm{CH}_{3} \mathrm{CN}$, toluene, and 2-ethoxyethanol were screened, among which none gave the products in good yields (Table 3, Entries 10-16). Furthermore, yields of 19\% and 49\% were obtained when 0.1 eq of imidazolium chloride and 0.5 eq of imidazolium chloride were used as the catalysts, respectively (Table 3, Entries 17 and 18). 
Table 3. Optimization of synthesis of medium ring heterocycles ${ }^{\mathrm{a}}$.

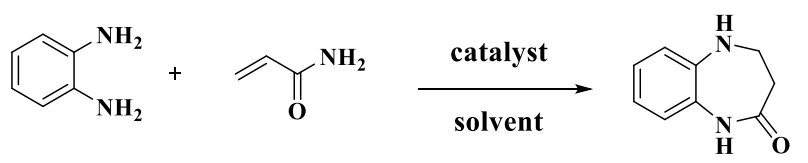

4

5

6

\begin{tabular}{|c|c|c|c|c|c|}
\hline Entry & Cat(eq) & Solvent & $\operatorname{Temp}\left({ }^{\circ} \mathrm{C}\right)$ & Time(h) & Yield(\%) \\
\hline 1 & Imidazolium chloride(0.3) & xylene & 120 & 5 & 45 \\
\hline 2 & - & xylene & 120 & 5 & $\mathrm{NO}$ \\
\hline 3 & $\mathrm{HCl}(0.3 \mathrm{eq})$ & xylene & 120 & 5 & 34 \\
\hline 4 & Imidazolium(0.3) & xylene & 120 & 5 & trace \\
\hline 5 & Imidazolium chloride(0.3) & xylene & 80 & 5 & 13 \\
\hline 6 & Imidazolium chloride(0.3) & xylene & 100 & 5 & 25 \\
\hline 7 & Imidazolium chloride(0.3) & xylene & 110 & 5 & 31 \\
\hline 8 & Imidazolium chloride(0.3) & xylene & 140 & 5 & 75 \\
\hline 9 & Imidazolium chloride(0.3) & xylene & 150 & 5 & 76 \\
\hline 10 & Imidazolium chloride(0.3) & $\mathrm{CH}_{3} \mathrm{CN}$ & 70 & 9 & 15 \\
\hline 11 & Imidazolium chloride(0.3) & $\mathrm{H}_{2} \mathrm{O}$ & 100 & 9 & 10 \\
\hline 12 & Imidazolium chloride(0.3) & dioxane & 100 & 9 & 27 \\
\hline 13 & Imidazolium chloride(0.3) & toluene & 110 & 9 & 10 \\
\hline 14 & Imidazolium chloride(0.3) & ethylene glycol diethyl ether & 120 & 5 & 39 \\
\hline 15 & Imidazolium chloride(0.3) & 2-methoxyethanol & 125 & 5 & 43 \\
\hline 16 & Imidazolium chloride(0.3) & 2-ethoxyethanol & 140 & 5 & trace \\
\hline 17 & Imidazolium chloride $(0.1)$ & xylene & 140 & 5 & 19 \\
\hline 18 & Imidazolium chloride(0.5) & xylene & 140 & 5 & 49 \\
\hline
\end{tabular}

a General conditions: 4 (4.6 mmol, 1 equiv), 5 (7.9 mmol, 1.7 equiv), imidazolium chloride (0.1-0.5 equiv) under solvent-free conditions for $6 \mathrm{~h}$; ${ }^{\mathrm{b}}$ Isolated yields are given. All solvents are $2 \mathrm{~mL}$. Abbreviations: NO, no reaction.

\subsection{Scope of Substituted Substrate}

With the optimized reaction conditions on hand, the scope of the Michael addition reactions was explored using a wide range of amines and acrylamide derivatives, as shown in Table 4. Firstly, aniline reacted with $\mathrm{N}, \mathrm{N}$-dimethylacrylamide to form the corresponding Michael addition product in a yield of $74 \%$ (Table 4, 3a). Aromatic amine substituted with electron-donating groups (e.g., amino, methoxy, or phenyl) at different positions reacted very well with $N, N$-dimethylacrylamide, generating the corresponding products in moderate to good yields (Table 4, 3b-3e). Similarly, aromatic amine possessing a weak electron-withdrawing group, such as 4-bromoaniline, underwent a smooth reaction to obtain a medium yield of the corresponding product 3 (Table $4, \mathbf{3 f}$ and $\mathbf{3 g}$ ). However, it is worth noting that aromatic amines substituted by a strong electron withdrawing group did not react with $\mathrm{N}, \mathrm{N}$-dimethylacrylamide (Table 4, 3h). Moreover, to further investigate the scope of this reaction system, the reactions of different substituted amines and acrylamide derivatives (e.g., acrylamide $\mathrm{N}, \mathrm{N}$-dimethylacrylamide, methyl acrylate, ethyl acrylate or tert-butyl acrylate) were also tested. Aromatic amine bearing either electron-rich or weak electron-deficient substituents all underwent the reactions smoothly to give the expected products in yields of $33 \%$ to $88 \%$ (Table $4,3 \mathbf{i}-3 \mathbf{v}$ ). However, the representative of the heterocyclic aromatic amines such as 2-aminopyridine could be transformed into the corresponding product in a yield of $33 \%$. The lower yield was ascribed to lower nucleophilicity of heterocyclic aromatic amines (Table 4,3 s). The reaction of secondary amines with acrylamide was further tested. The secondary arylamine $\mathrm{N}$-methylaniline was converted into the corresponding product in excellent yields (Table 4, 3w). Encouraged by these satisfying results, aza-Michael addition of various aliphatic amines and acrylamide were performed. The aza-Michael addition of pyrrolidine and 4-methylpiperidine could also proceed smoothly within shorter reaction period, obtaining the corresponding products in good yields (Table 4, $3 \mathbf{x}$ and $3 \mathbf{y}$ ). The higher yields might be attributed to the stronger nucleophilicity of aliphatic amines. 
Table 4. Substrate scope of substituted amines and acrylamide derivatives a ${ }^{\text {. }}$

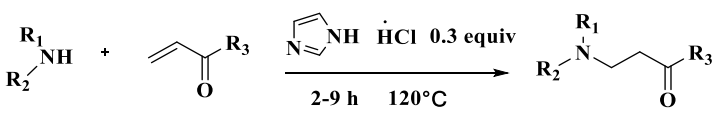

$$
\begin{aligned}
& 1 \quad 2 \quad 3 b \\
& \mathrm{R}_{1}=\mathrm{H}, \mathrm{CH}_{3} \quad \mathrm{R}_{2}=\text { Aromatic } \\
& \mathrm{R}_{3}=\mathrm{NH}_{2},\left(\mathrm{CH}_{3}\right)_{2} \mathrm{~N},\left(\mathrm{C}_{2} \mathrm{H}_{6}\right)_{2} \mathrm{~N}, \mathrm{CH}_{3} \mathrm{O}, \mathrm{C}_{2} \mathrm{H}_{6} \mathrm{O},\left(\mathrm{CH}_{3}\right)_{3} \mathrm{CO}
\end{aligned}
$$<smiles>CC(C)(C)C(=O)CCCC(=O)c1ccccc1</smiles>

3a

4h, $74 \%$ yield<smiles>CN(C)C(=O)CCNc1ccccc1Cl</smiles>

$8 \mathrm{~h}, \mathbf{8 2} \%$ yield<smiles>CCN(CC)C(=O)CCNc1ccccc1</smiles>

$3 \mathbf{k}$

$5 \mathrm{~h}, 83 \%$ yield<smiles>COC(=O)CCNc1ccccc1</smiles>

$3 q$

$2 \mathrm{~h}, \mathbf{8 8} \%$ yield $^{\mathrm{c}}$<smiles>CC(C)(C)OC(=O)CCNc1ccc(Cl)cc1</smiles><smiles>CN(C)C(=O)CCNc1ccccc1N</smiles>

$6 \mathrm{~h}, 72 \%$ yield<smiles>CN(C)C(=O)CCNc1ccc(Br)cc1</smiles>

$7 \mathrm{~h}, 55 \%$ yield<smiles>CCN(CC)C(=O)CCNc1ccc(C)cc1</smiles>

31

2h, $72 \%$ yield<smiles>CCOC(=O)CCNc1ccc(C)cc1</smiles>

$3 \mathbf{r}$

$7 \mathrm{~h}, 82 \%$ yield $^{\mathrm{c}}$<smiles>CN(CCC(N)=O)c1ccccc1</smiles>

$3 w$<smiles>CN(C)C(=O)CCNC(=O)c1ccccc1N</smiles>

$6 \mathrm{~h}, 43 \%$ yield<smiles>CN(C)C(=O)CCNc1ccc([N+](=O)[O-])cc1</smiles>

7h, NR<smiles>CCN(CC)C(=O)CCNc1ccccc1N</smiles>

$3 \mathrm{~m}$

$6 h, 63 \%$ yield

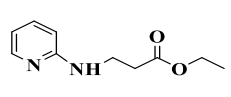

$3 \mathrm{~s}$

$5 h, 33 \%$ yield $^{c}$<smiles>NC(=O)CCN1CCCC1</smiles>

$3 \mathbf{x}$

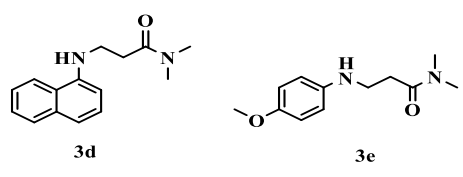

3h, $73 \%$ yield

2h, $81 \%$ yield<smiles>NC(=O)CCCNc1ccccc1</smiles>

$4 \mathrm{~h}, 84 \%$ yield<smiles>CCN(CC)C(=O)CCNc1cccc(Cl)c1</smiles>

30

$4 \mathrm{~h}, 76 \%$ yield<smiles>NC(=O)CCNc1ccc(Br)cc1</smiles>

$5 \mathrm{~h}, 79 \%$ yield<smiles>CCN(CC)C(=O)CCNCc1ccccc1</smiles>

$3 \mathbf{p}$

$5 \mathrm{~h}, \mathbf{8 4} \%$ yield<smiles>Cc1ccc(NCCC(=O)OC(C)(C)C)cc1</smiles>

3t

$6 \mathrm{~h}, 81 \%$ yield $^{\mathrm{c}}$<smiles>CC(C)(C)OC(=O)CCCNc1ccccc1</smiles>

$3 \mathbf{u}$

$7 \mathrm{~h}, \mathbf{8 0} \%$ yield $^{\mathrm{c}}$<smiles>CC1CCN(CCC(N)=O)CC1</smiles>

$3 y, 94 \%$ yield $^{e}$

a Reaction conditions: Unless otherwise noted, 1 ( $5 \mathrm{mmol}, 1$ equiv), 2 ( $6.5 \mathrm{mmol}, 1.3$ equiv), imidazolium chloride $(0.3$ equiv), solvent-free conditions, $2-9 \mathrm{~h}$, at $120^{\circ} \mathrm{C}^{\mathrm{b}}$ Yields after column purification; ${ }^{\mathrm{c}}$ This reaction was performed at $100^{\circ} \mathrm{C} ;{ }^{d}$ This reaction was performed for $0.5 \mathrm{~h}$ at rt. ${ }^{\mathrm{e}}$ This reaction was performed for $10 \mathrm{~min}$ at $70^{\circ} \mathrm{C}$. Abbreviations: $\mathrm{NR}$, no reaction.

After the amino group was protected, substrate ranges of the deprotection of aromatic amino groups were investigated and the results were displayed in Table 5. Heating a solution of $\mathrm{N}, \mathrm{N}$-Dimethyl-3-phenylamino-propionamide (3aa) using 0.7 eq of imidazolium chloride at $150{ }^{\circ} \mathrm{C}$ without solvent resulted in the formation of aniline in a yield of $63 \%$ (Table $5,1 a)$. The use of substrates with electron-donating substituents generally resulted in higher yields than the substrates with a weak electron-withdrawing substituent such as $\mathrm{Cl}, \mathrm{Br}$ (Table 5, 1b-1f). Next, when the dimethylamino substituent was replaced by $-\mathrm{NH}_{2}$ or diethylamino, the yields were $35-81 \%$ (Table $5, \mathbf{1 g}-\mathbf{1 j}$ ). Meanwhile, $R_{3}$ substituents such as ethoxy and Tert-butoxy groups were tolerable under these optimized conditions. Compound 3bk-3bo gave the corresponding product in medium yields (Table 5, 1k-1o). 
Table 5. Substrate scope of the deprotection of aromatic amino groups ${ }^{\text {a }}$.

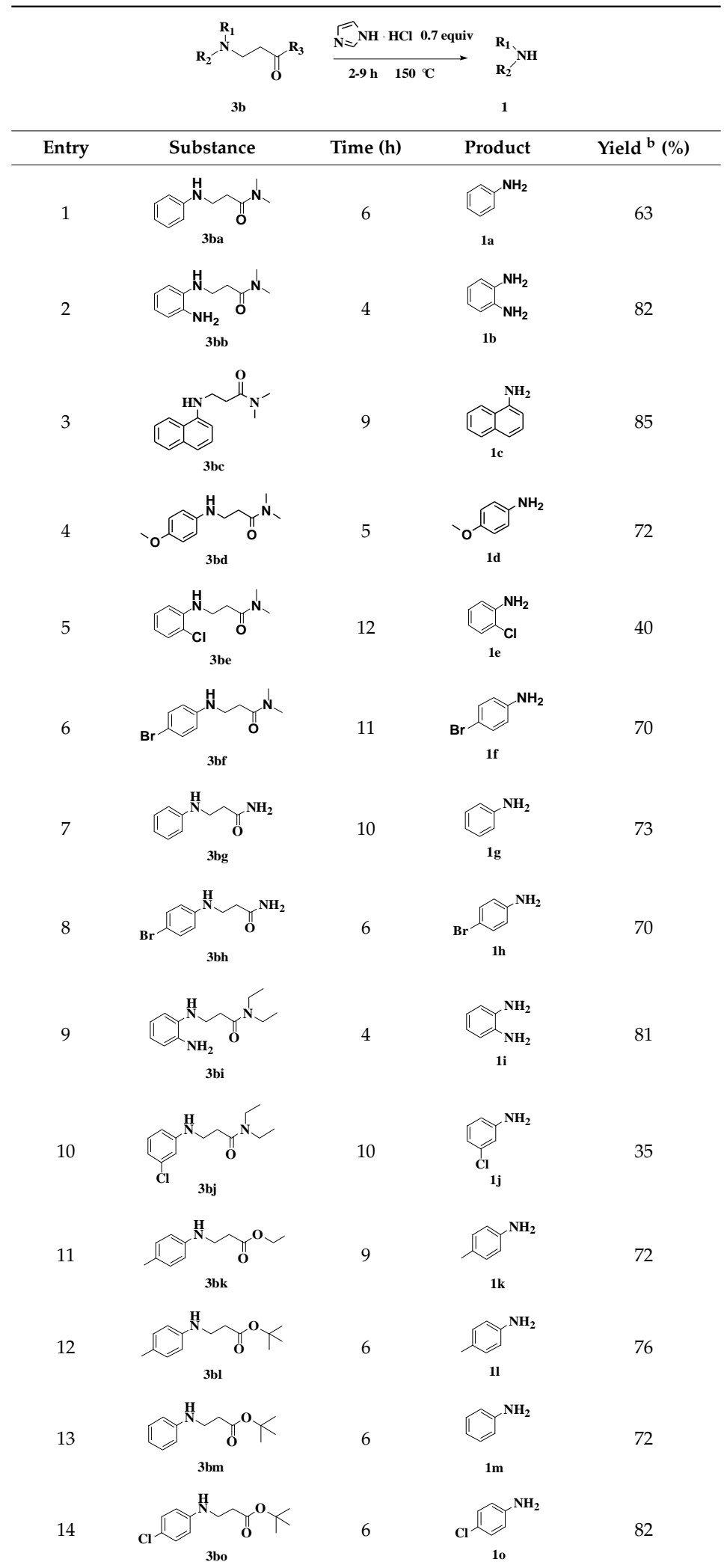

a Reaction conditions: Unless otherwise noted, All reactions were carried out with $\mathbf{3 b}$ ( $1.0 \mathrm{mmol}, 1$ equiv) and imidazolium chloride ( $0.7 \mathrm{mmol}, 0.7$ equiv), under solvent-free conditions for $4-11 \mathrm{~h}$ at $150{ }^{\circ} \mathrm{C}$; ${ }^{\mathrm{b}}$ Yields after column purification. Abbreviations: NR, no reaction. 
Then, we investigated the functional group tolerance on a seven-membered ring. The data were presented in Table 6. O-phenylenediamine and acrylamide derivatives reacted well, leading to the corresponding products in moderate to good yields (Table 6, 6a-6d). It is worth noting that o-phenylenediamine and $\mathrm{N}, \mathrm{N}$-dimethylacrylamide or tert-Butyl acrylate reactions were not observed under these reaction conditions. The disubstituted o-phenylenediamine (such as 4,5-difluoro-2-phenylenediamine) and acrylamide derivatives were compatible in this reaction, obtaining the corresponding products in good yields (Table 6, 6e). We explored the reaction of 2-aminothiophenol with acrylamide or methacrylamide under standard reaction conditions, providing the corresponding product in yields of $34 \%$ and $31 \%$ (Table $6, \mathbf{6 f}$ and $\mathbf{6 g}$ ). These low yields might be attributed to more by-products of the Michael addition reaction.

Table 6. Substrate scope of substituted 1,3,4,5-tetrahydro-2H-1,5-benzodiazepine-2-ones and substituted 2,3-dihydrobenzo[b][1,4]thiazepin-4(5H)-ones ${ }^{\mathrm{a}}$.

(n)

a Reaction conditions: Unless otherwise noted, $\mathbf{4 a}(3.0 \mathrm{mmol}, 1 \mathrm{eq})$ and $\mathbf{5 a}(5.1 \mathrm{mmol}, 1.7 \mathrm{eq})$, imidazolium chloride (0.3 equiv), at $140{ }^{\circ} \mathrm{C} ;{ }^{\mathrm{b}}$ Yields after column purification; ${ }^{\mathrm{c}}$ This reaction was performed at $90^{\circ} \mathrm{C}$ for $5 \mathrm{~h}$ and then at $140{ }^{\circ} \mathrm{C}$ for $8 \mathrm{~h}$. Abbreviations: NR, no reaction. 


\section{Conclusions}

In conclusion, we have developed a highly efficient and environmentally friendly method for amino protection and seven-membered ring construction. The reactions initiated by aza-Michael reactions to protect the amino group, followed by deprotection of the amino group or transaminated. This method has a wide scope of substrates, providing a wide range of aromatic amines and aliphatic amines. Also, the significance of our finding can reduce the number or amount of organic solvents, potentially toxicity, and hazardous catalysts. It is most important that we have used non-metallic catalysts and compared them with the other metal catalysts. Moreover, the results provide further evidence that it is possible to use this method in the synthesis of bioactive compounds. It is noteworthy that this method is complementary to the previously reported amino protective reactions.

\section{Materials and Methods}

\subsection{Chemicals and Materials}

All reagents were purchased from Meyer Reagent Co., Ltd. (Shanghai, China), Macklin Reagent Co., Ltd. (Shanghai, China), Chongqing Chuandong Chemical Co., Ltd. (Chongqing, China), etc., and used without further purification. ${ }^{1} \mathrm{H}$ - and ${ }^{13} \mathrm{C}-\mathrm{NMR}$ spectra were recorded on a Bruker Avancell NMR $(600 \mathrm{MHz})$ instruments. Chemical shifts were reported in ppm and coupling constants $(J)$ in Hz. TLC plates were visualized by exposing UV light or by iodine. Purification of crude compounds and separation of reaction mixtures were carried out by column chromatography using silica gel (200-300 meshes, Shanghai, China). All substrates are known compounds according to the literature.

\subsection{General Procedures for Michael Addition Reaction}

The $1(5.0 \mathrm{mmol})$ and $2(6.5 \mathrm{mmol})$ in a molar ratio of 1:1.3 reacted with stirring in the presence of imidazolium hydrochloride ( $1.5 \mathrm{mmol}, 0.3 \mathrm{eq})$. Heating was performed using an oil bath and the reaction was followed up by TLC until completion. After completion of the reaction, the system was cooled. The organic layer was extracted using water $(15 \mathrm{~mL})$ and ethyl acetate $(20 \mathrm{~mL})$ and dried using anhydrous $\mathrm{Na}_{2} \mathrm{SO}_{4}$, filtered, and concentrated under reduced pressure. The residue was subjected to column chromatography eluting with petroleum ether: ethyl acetate (7:1) mixtures.

\subsubsection{Synthesis of 3-(Pyrrolidin-1-yl)propanamide (3x)}

To a mixture of pyrrolidine (7.0 mmol, 1 equiv) and acrylamide (9.2 mmol, 1.3 equiv), imidazolium hydrochloride ( $2.1 \mathrm{mmol}, 0.3 \mathrm{eq}$ ) was added. The mixture was stirred at RT and monitored by TLC. After the reaction completed, the reaction mixture was cooled to allow the products crystallize (ethyl acetate/methanol (5:1)). The crystallized products were filtered and further washed by ethyl acetate, dried, and evaluated by spectral analysis $(3 \mathbf{x})$.

\subsubsection{Synthesis of 3-(4-Methylpiperidin-1-yl)propanamide (3y)}

To a mixture of 4-methylpiperidine ( $5.1 \mathrm{mmol}, 1$ equiv) and acrylamide (9.2 mmol, 1.3 equiv), imidazolium hydrochloride $(2.1 \mathrm{mmol}, 0.3 \mathrm{eq})$ was added. The mixture was stirred at $70{ }^{\circ} \mathrm{C}$ and monitored by TLC. After the reaction completed, the reaction mixture was cooled to allow the products to crystallize (ethyl acetate/methanol (5:1)). The crystallized products were filtered, and further washed by ethyl acetate, dried, and evaluated by spectral analysis (3y).

\subsection{General Procedure for Amino Deprotection}

Placed $3 \mathbf{b}$ ( $1 \mathrm{mmol}, 1$ equiv) and imidazolium chloride ( $0.7 \mathrm{mmol}, 0.7$ equiv) in a tube-type schlenk flask, stirred at $150{ }^{\circ} \mathrm{C}$, and monitored the reaction progress by TLC. After the reaction completed, the reaction mixture was cooled. The organic layer was extracted using water $(15 \mathrm{~mL})$ and ethyl acetate $(20 \mathrm{~mL})$ and dried using anhydrous $\mathrm{Na}_{2} \mathrm{SO}_{4}$, then filtered and concentrated under reduced pressure. 
The residue was subjected to column chromatography eluting with petroleum ether: ethyl acetate (10:1) mixtures.

4.4. General Methods for Synthesis of Substituted 1,3,4,5-Tetrahydro-2H-1,5-benzodiazepine-2-ones and Substituted 2,3-Dihydrobenzo[b][1,4] thiazepin-4(5H)-ones

To $20 \mathrm{~mL}$ of schlenk tube with a magnetic stir bar we successively added $4 \mathbf{a}(3.0 \mathrm{mmol}, 1 \mathrm{eq}), \mathbf{5 a}$ ( $5.1 \mathrm{mmol}, 1.7 \mathrm{eq})$, and imidazolium hydrochloride $(0.9 \mathrm{mmol}, 0.3 \mathrm{eq})$. Then we added xylene $(1 \mathrm{~mL})$ to the reaction mixture. The mixture was stirred at $140{ }^{\circ} \mathrm{C}$. The progress of the reaction was monitored by TLC. After the reaction completed, water $(15 \mathrm{~mL})$ was added to the reaction mixture. The solution was extracted using ethyl acetate $(3 \times 15 \mathrm{~mL})$ and dried using anhydrous $\mathrm{Na}_{2} \mathrm{SO}_{4}$. The crude product was purified by flash chromatography eluting with petroleum ether: ethyl acetate (5:1) mixtures.

Synthesis of 1,3,4,5-Tetrahydro-2H-benzo[b][1,4]diazepin-2-one (6c)

To $20 \mathrm{~mL}$ of schlenk tube with a magnetic stir bar, o-phenylenediamine ( $4.6 \mathrm{mmol}, 0.5 \mathrm{~g}, 1 \mathrm{eq})$, methyl acrylate $(7.9 \mathrm{mmol}, 0.68 \mathrm{~g}, 1.7 \mathrm{eq})$ and imidazolium hydrochloride $(1.4 \mathrm{mmol}, 0.15 \mathrm{~g}, 0.3 \mathrm{eq})$ were successively added. Then xylene $(1 \mathrm{~mL})$ was added to the reaction mixture. The mixture was stirred at $90^{\circ} \mathrm{C}$ for $5 \mathrm{~h}$ and then at $140{ }^{\circ} \mathrm{C}$ for $8 \mathrm{~h}$. The progress of the reaction was monitored by TLC. After the reaction completed, water $(15 \mathrm{~mL})$ was added to the reaction mixture. The solution was extracted with ethyl acetate $(3 \times 15 \mathrm{~mL})$ and dried using anhydrous $\mathrm{Na}_{2} \mathrm{SO}_{4}$. The crude product was purified by flash chromatography using silica gel to obtain the corresponding product (6c) (Figures S1-S74).

N,N-Dimethyl-3-phenylamino-propionamide (3a): The product was obtained as a white solid in a yield of 74\% (0.34 g), MP: 103-106 ${ }^{\circ} \mathrm{C}$ [30]. ${ }^{1} \mathrm{HNMR}\left(600 \mathrm{MHz}, \mathrm{CDCl}_{3}\right) \delta 7.17(\mathrm{dd}, J=8.4,7.4 \mathrm{~Hz}, 2 \mathrm{H}), 6.69$ (t, $J=7.3 \mathrm{~Hz}, 1 \mathrm{H}), 6.64(\mathrm{~d}, J=7.7 \mathrm{~Hz}, 2 \mathrm{H}), 4.33(\mathrm{~s}, 1 \mathrm{H}), 3.48(\mathrm{t}, J=6.0 \mathrm{~Hz}, 2 \mathrm{H}), 2.95(\mathrm{~d}, J=3.5 \mathrm{~Hz}, 6 \mathrm{H})$, $2.59(\mathrm{t}, J=6.0 \mathrm{~Hz}, 2 \mathrm{H}) .{ }^{13} \mathrm{C}-\mathrm{NMR}\left(151 \mathrm{MHz}, \mathrm{CDCl}_{3}\right) \delta 171.62,147.72,129.29,117.57,113.26,39.58,37.09$, $35.28,32.20$.

3-(2-Amino-phenylamino)- $N, N$-dimethyl-propionamide (3b): The product was obtained as a black liquid in a yield of $72 \%(0.39 \mathrm{~g}) .{ }^{1} \mathrm{H}$ NMR $\left(600 \mathrm{MHz}, \mathrm{CDCl}_{3}\right) \delta 6.84-6.75(\mathrm{~m}, 1 \mathrm{H}), 6.75-6.64(\mathrm{~m}, 3 \mathrm{H}), 3.59(\mathrm{~s}$, $2 \mathrm{H}), 3.46(\mathrm{t}, \mathrm{J}=6.2 \mathrm{~Hz}, 2 \mathrm{H}), 2.96(\mathrm{~d}, J=9.6 \mathrm{~Hz}, 6 \mathrm{H}), 2.63(\mathrm{t}, J=6.1 \mathrm{~Hz}, 2 \mathrm{H}) \cdot{ }^{13} \mathrm{C}-\mathrm{NMR}\left(151 \mathrm{MHz}, \mathrm{CDCl}_{3}\right)$ $\delta 171.73,136.94,135.20,120.21,119.03,116.33,112.65,40.06,37.11,35.31,32.44$.

2-Amino-N-(2-dimethylcarbamoyl-ethyl)-benzamide (3c): The product was obtained as a white solid in a yield of $43 \%$ (0.23 g). MP: $134-136{ }^{\circ} \mathrm{C} .{ }^{1} \mathrm{H}$ NMR $\left(600 \mathrm{MHz}, \mathrm{CDCl}_{3}\right) \delta 8.04(\mathrm{~s}, 1 \mathrm{H}), 7.41(\mathrm{~d}, J=7.9 \mathrm{~Hz}$, $1 \mathrm{H}), 7.34(\mathrm{t}, J=7.8 \mathrm{~Hz}, 1 \mathrm{H}), 6.80(\mathrm{~d}, J=8.4 \mathrm{~Hz}, 1 \mathrm{H}), 6.61(\mathrm{t}, J=7.5 \mathrm{~Hz}, 1 \mathrm{H}), 5.84(\mathrm{~s}, 2 \mathrm{H}), 3.55(\mathrm{t}, J=$ $7.3 \mathrm{~Hz}, 2 \mathrm{H}), 3.00(\mathrm{~s}, 3 \mathrm{H}), 2.96(\mathrm{~s}, 3 \mathrm{H}), 2.68(\mathrm{t}, J=7.3 \mathrm{~Hz}, 2 \mathrm{H}) .{ }^{13} \mathrm{C} \mathrm{NMR}\left(151 \mathrm{MHz}, \mathrm{CDCl}_{3}\right) \delta 172.03$, $171.13,149.76,133.62,128.45,114.89,113.43,112.02,39.16,37.25,35.37,32.86$.

N,N-Dimethyl-3-(naphthalen-1-ylamino)-propionamide (3d): The product was obtained as a colorless liquid in a yield of $73 \%(0.52 \mathrm{~g}) .{ }^{1} \mathrm{H}-\mathrm{NMR}\left(600 \mathrm{MHz}, \mathrm{CDCl}_{3}\right) \delta 7.77(\mathrm{~d}, J=7.9 \mathrm{~Hz}, 1 \mathrm{H}), 7.69(\mathrm{~d}, J=$ $7.8 \mathrm{~Hz}, 1 \mathrm{H}), 7.39-7.28(\mathrm{~m}, 2 \mathrm{H}), 7.26(\mathrm{t}, J=7.8 \mathrm{~Hz}, 1 \mathrm{H}), 7.18-7.10(\mathrm{~m}, 1 \mathrm{H}), 6.57(\mathrm{~d}, J=7.5 \mathrm{~Hz}, 1 \mathrm{H}), 5.64-$ $4.87(\mathrm{~m}, 1 \mathrm{H}), 3.56(\mathrm{t}, J=5.8 \mathrm{~Hz}, 2 \mathrm{H}), 2.86(\mathrm{~d}, J=6.3 \mathrm{~Hz}, 6 \mathrm{H}), 2.62(\mathrm{t}, J=5.8 \mathrm{~Hz}, 2 \mathrm{H}) .{ }^{13} \mathrm{C}-\mathrm{NMR}(151 \mathrm{MHz}$, $\left.\mathrm{CDCl}_{3}\right) \delta 171.86,143.27,134.42,128.48,126.53,125.77,124.76,123.87,120.40,117.37,104.31,39.73,37.15$, $35.36,31.92$.

3-(4-Methoxy-phenylamino)-N,N-dimethyl-propionamide (3e): The product was obtained as a white solid in a yield of $81 \%(0.5 \mathrm{~g})$. MP: $85-87^{\circ} \mathrm{C} .{ }^{1} \mathrm{H}-\mathrm{NMR}\left(600 \mathrm{MHz}, \mathrm{CDCl}_{3}\right) 86.78(\mathrm{~d}, J=8.6 \mathrm{~Hz}, 2 \mathrm{H}), 6.64(\mathrm{~d}, J=$ $8.6 \mathrm{~Hz}, 2 \mathrm{H}), 3.75(\mathrm{~s}, 3 \mathrm{H}), 3.43(\mathrm{t}, J=5.9 \mathrm{~Hz}, 2 \mathrm{H}), 2.96(\mathrm{~d}, J=6.5 \mathrm{~Hz}, 6 \mathrm{H}), 2.59(\mathrm{t}, J=5.9 \mathrm{~Hz}, 2 \mathrm{H}) .{ }^{13} \mathrm{C}$ NMR $\left(151 \mathrm{MHz}, \mathrm{CDCl}_{3}\right) \delta$ 171.72, 152.41, 141.82, 114.92, 114.91, 55.80, 40.83, 37.12, 35.30, 32.18.

3-(2-Chloro-phenylamino)-N,N-dimethyl-propionamide (3f): The product was obtained as a yellow liquid in a yield of $82 \%(0.52 \mathrm{~g}) .{ }^{1} \mathrm{H}$ NMR $\left(600 \mathrm{MHz}, \mathrm{CDCl}_{3}\right) \delta 7.24(\mathrm{dd}, J=7.9,1.5 \mathrm{~Hz}, 1 \mathrm{H}), 7.15-7.11(\mathrm{~m}$, 
$1 \mathrm{H}), 6.71(\mathrm{dd}, J=8.2,1.1 \mathrm{~Hz}, 1 \mathrm{H}), 6.61(\mathrm{tt}, J=14.6,7.3 \mathrm{~Hz}, 1 \mathrm{H}), 4.92(\mathrm{~s}, 1 \mathrm{H}), 3.54(\mathrm{t}, J=6.4 \mathrm{~Hz}, 2 \mathrm{H}), 2.96$ $(\mathrm{d}, J=2.3 \mathrm{~Hz}, 6 \mathrm{H}), 2.62(\mathrm{t}, J=6.4 \mathrm{~Hz}, 2 \mathrm{H}) .{ }^{13} \mathrm{C} \mathrm{NMR}\left(151 \mathrm{MHz}, \mathrm{CDCl}_{3}\right) \delta 170.16,142.73,128.25,126.74$, $118.56,116.21,110.12,38.30,36.08,34.30,31.33$.

3-(4-Bromo-phenylamino)-N,N-dimethyl-propionamide (3g): The product was obtained as a white solid in a yield of $55 \%(0.47 \mathrm{~g})$. MP: $110-113{ }^{\circ} \mathrm{C} .{ }^{1} \mathrm{H}$ NMR $\left(600 \mathrm{MHz}, \mathrm{CDCl}_{3}\right) 87.24(\mathrm{~d}, J=8.8 \mathrm{~Hz}, 2 \mathrm{H}), 6.52(\mathrm{~d}, J$ $=8.8 \mathrm{~Hz}, 2 \mathrm{H}), 4.65(\mathrm{~s}, 1 \mathrm{H}), 3.44(\mathrm{t}, J=5.9 \mathrm{~Hz}, 2 \mathrm{H}), 2.96(\mathrm{~d}, J=8.4 \mathrm{~Hz}, 6 \mathrm{H}), 2.58(\mathrm{t}, J=5.9 \mathrm{~Hz}, 2 \mathrm{H}) \cdot{ }^{13} \mathrm{C}$ NMR $\left(151 \mathrm{MHz}, \mathrm{CDCl}_{3}\right) \delta$ 171.46, 146.80, 131.97, 114.83, 109.08, 39.58, 37.11, 35.32, 31.95.

3-Phenylamino-propionamide (3i): The product was obtained as a white solid in a yield of $84 \%(0.39 \mathrm{~g})$. MP: $53-56{ }^{\circ} \mathrm{C}[31] .{ }^{1} \mathrm{H}$ NMR $\left(600 \mathrm{MHz}, \mathrm{CDCl}_{3}\right) \delta 7.18(\mathrm{t}, J=7.9 \mathrm{~Hz}, 2 \mathrm{H}), 6.73(\mathrm{t}, J=7.3 \mathrm{~Hz}, 1 \mathrm{H}), 6.63(\mathrm{~d}$, $J=7.9 \mathrm{~Hz}, 2 \mathrm{H}), 5.91(\mathrm{~s}, 2 \mathrm{H}), 3.44(\mathrm{t}, J=6.1 \mathrm{~Hz}, 2 \mathrm{H}), 2.49(\mathrm{t}, J=6.1 \mathrm{~Hz}, 2 \mathrm{H}) .{ }^{13} \mathrm{C} \mathrm{NMR}\left(151 \mathrm{MHz}, \mathrm{CDCl}_{3}\right)$ $\delta 174.26,147.54,129.38,118.09,113.40,39.99,34.91$.

3-(4-Bromo-phenylamino)-propionamide (3j): The product was obtained as a white solid in a yield of $79 \%$ (0.68 g). MP: $122-125^{\circ} \mathrm{C} .{ }^{1} \mathrm{H}$ NMR $\left(600 \mathrm{MHz}, \mathrm{CDCl}_{3}\right) \delta 7.29-7.28(\mathrm{~m}, 1 \mathrm{H}), 7.27(\mathrm{~d}, J=2.1 \mathrm{~Hz}, 1 \mathrm{H})$, $6.64-6.47(\mathrm{~m}, 2 \mathrm{H}), 5.57(\mathrm{~d}, 2 \mathrm{H}), 3.48-3.41(\mathrm{~m}, 2 \mathrm{H}), 2.59-2.50(\mathrm{~m}, 2 \mathrm{H}) .{ }^{13} \mathrm{C} \mathrm{NMR}\left(151 \mathrm{MHz}, \mathrm{CDCl}_{3}\right) \delta$ $173.48,146.05,132.10,115.26,110.16,40.19,34.28$.

$\mathrm{N}, \mathrm{N}$-Diethyl-3-phenylamino-propionamide (3k)[32]: The product was obtained as a yellow liquid in a yield of $83 \%(0.39 \mathrm{~g}) .{ }^{1} \mathrm{H}$ NMR $\left(600 \mathrm{MHz}, \mathrm{CDCl}_{3}\right) \delta 7.21-7.11(\mathrm{~m}, 2 \mathrm{H}), 6.68(\mathrm{t}, J=7.3 \mathrm{~Hz}, 1 \mathrm{H}), 6.64-$ $6.61(\mathrm{~m}, 2 \mathrm{H}), 4.10(\mathrm{~m}, 1 \mathrm{H}), 3.46(\mathrm{t}, J=6.2 \mathrm{~Hz}, 2 \mathrm{H}), 3.36(\mathrm{q}, J=7.1 \mathrm{~Hz}, 2 \mathrm{H}), 3.23(\mathrm{q}, J=7.2 \mathrm{~Hz}, 2 \mathrm{H}), 2.57$ $(\mathrm{t}, J=6.2 \mathrm{~Hz}, 2 \mathrm{H}), 1.10(\mathrm{td}, J=7.1,5.6 \mathrm{~Hz}, 6 \mathrm{H}) .{ }^{13} \mathrm{C} \mathrm{NMR}\left(151 \mathrm{MHz}, \mathrm{CDCl}_{3}\right) \delta 170.75,148.04,129.25$, $117.35,113.18,41.90,40.13,39.75,32.00,14.16,13.11$.

N,N-Diethyl-3-p-tolylamino-propionamide (31): The product was obtained as a white solid in a yield of $72 \%$ (0.39 g). MP: $52-55^{\circ} \mathrm{C} .{ }^{1} \mathrm{H}$ NMR $\left(600 \mathrm{MHz}, \mathrm{CDCl}_{3}\right) \delta 6.98(\mathrm{~d}, J=8.3 \mathrm{~Hz}, 2 \mathrm{H}), 6.57(\mathrm{~d}, J=8.3 \mathrm{~Hz}$, $2 \mathrm{H}), 3.45(\mathrm{t}, J=6.1 \mathrm{~Hz}, 2 \mathrm{H}), 3.37(\mathrm{q}, J=7.1 \mathrm{~Hz}, 2 \mathrm{H}), 3.25(\mathrm{q}, J=7.2 \mathrm{~Hz}, 2 \mathrm{H}), 2.58(\mathrm{t}, J=6.1 \mathrm{~Hz}, 2 \mathrm{H}), 2.23$ $(\mathrm{s}, 3 \mathrm{H}), 1.11(\mathrm{td}, J=7.1,3.1 \mathrm{~Hz}, 6 \mathrm{H}) .{ }^{13} \mathrm{C}$ NMR $\left(151 \mathrm{MHz}, \mathrm{CDCl}_{3}\right) \delta 170.77,145.45,129.78,126.96,113.66$, $41.87,40.41,40.09,31.96,20.41,14.17,13.11$.

3-(2-Amino-phenylamino)-N,N-diethyl-propionamide (3m): The product was obtained as a black liquid in a yield of $63 \%(0.34 \mathrm{~g}) .{ }^{1} \mathrm{H}$ NMR $\left(600 \mathrm{MHz}, \mathrm{CDCl}_{3}\right) \delta 6.82-6.77(\mathrm{~m}, 1 \mathrm{H}), 6.75-6.69(\mathrm{~m}, 3 \mathrm{H}), 3.85(\mathrm{~s}$, $2 \mathrm{H}), 3.47(\mathrm{t}, J=6.2 \mathrm{~Hz}, 2 \mathrm{H}), 3.39(\mathrm{q}, J=7.1 \mathrm{~Hz}, 2 \mathrm{H}), 3.29(\mathrm{q}, J=7.2 \mathrm{~Hz}, 2 \mathrm{H}), 2.65(\mathrm{t}, J=6.2 \mathrm{~Hz}, 2 \mathrm{H}), 1.14$ $(\mathrm{dt}, J=13.9,7.1 \mathrm{~Hz}, 6 \mathrm{H}) .{ }^{13} \mathrm{C}$ NMR $\left(151 \mathrm{MHz}, \mathrm{CDCl}_{3}\right) \delta 170.87,136.52,135.44,120.22,119.48,116.43$, $113.28,41.94,40.62,40.17,32.06,14.21,13.12$.

3-(3-Chloro-phenylamino)- $N, N$-diethyl-propionamide (3o): The product was obtained as a white solid in a yield of $76 \%(0.48 \mathrm{~g}) . \mathrm{MP}: 58-61{ }^{\circ} \mathrm{C} .{ }^{1} \mathrm{H}$ NMR $\left(600 \mathrm{MHz}, \mathrm{CDCl}_{3}\right) \delta 7.04(\mathrm{t}, J=8.0 \mathrm{~Hz}, 1 \mathrm{H}), 6.65-6.61$ $(\mathrm{m}, 1 \mathrm{H}), 6.59(\mathrm{t}, J=2.1 \mathrm{~Hz}, 1 \mathrm{H}), 6.49(\mathrm{dd}, J=8.2,2.2 \mathrm{~Hz}, 1 \mathrm{H}), 4.58(\mathrm{~m}, 1 \mathrm{H}), 3.49-3.41(\mathrm{~m}, 2 \mathrm{H}), 3.37(\mathrm{q}, J$ $=7.1 \mathrm{~Hz}, 2 \mathrm{H}), 3.25(\mathrm{q}, J=7.2 \mathrm{~Hz}, 2 \mathrm{H}), 2.57(\mathrm{t}, J=6.0 \mathrm{~Hz}, 2 \mathrm{H}), 1.18-0.99(\mathrm{~m}, 6 \mathrm{H}) .{ }^{13} \mathrm{C} \mathrm{NMR}(151 \mathrm{MHz}$, $\left.\mathrm{CDCl}_{3}\right) \delta 171.73,136.94,135.20,120.21,119.03,116.33,112.65,40.06,37.11,35.31,32.44$.

3-Benzylamino-N,N-diethyl-propionamide (3p): The product was obtained as a white solid in a yield of 84\% (0.45 g). MP: $119-121^{\circ} \mathrm{C} .{ }^{1} \mathrm{H}$ NMR (600 MHz, DMSO-d6) $\delta 9.44(\mathrm{~s}, 1 \mathrm{H}), 7.68-7.51(\mathrm{~m}, 2 \mathrm{H}), 7.51-$ $7.37(\mathrm{~m}, 3 \mathrm{H}), 4.26-4.04(\mathrm{~m}, 2 \mathrm{H}), 3.27(\mathrm{q}, J=7.1 \mathrm{~Hz}, 4 \mathrm{H}), 3.05(\mathrm{t}, J=7.1 \mathrm{~Hz}, 2 \mathrm{H}), 2.83(\mathrm{t}, J=7.2 \mathrm{~Hz}, 2 \mathrm{H})$, $1.11(\mathrm{t}, J=7.1 \mathrm{~Hz}, 3 \mathrm{H}), 1.02(\mathrm{t}, J=7.1 \mathrm{~Hz}, 3 \mathrm{H}) .{ }^{13} \mathrm{C}$ NMR (151 MHz, DMSO-d6) $\delta 168.78,132.51,130.46$, $129.32,129.12,50.27,43.13,41.74,40.38,40.24,40.11,29.02,14.40,13.47$.

3-Phenylamino-propionic acid methyl ester (3q): The product was obtained as a white solid in a yield of 88\% (0.41 g). MP: $32-35{ }^{\circ} \mathrm{C}[33] .{ }^{1} \mathrm{H}$ NMR $\left(600 \mathrm{MHz}, \mathrm{CDCl}_{3}\right) \delta 7.17(\mathrm{t}, J=7.6 \mathrm{~Hz}, 2 \mathrm{H}), 6.71(\mathrm{t}, J=7.3 \mathrm{~Hz}$, $1 \mathrm{H}), 6.61(\mathrm{~d}, J=8.1 \mathrm{~Hz}, 2 \mathrm{H}), 4.02(\mathrm{~s}, 1 \mathrm{H}), 3.68(\mathrm{~s}, 3 \mathrm{H}), 3.43(\mathrm{t}, J=6.4 \mathrm{~Hz}, 2 \mathrm{H}), 2.60(\mathrm{t}, J=6.4 \mathrm{~Hz}, 2 \mathrm{H}) .{ }^{13} \mathrm{C}$ NMR $\left(151 \mathrm{MHz}, \mathrm{CDCl}_{3}\right) \delta 172.85,147.60,129.52,129.35,129.15,117.91,117.75,117.54,113.24,113.06$, $112.83,99.99,51.78,39.43,33.73$. 
3-p-Tolylamino-propionic acid ethyl ester (3r) [34]: The product was obtained as a yellow liquid in a yield of $82 \%(0.44 \mathrm{~g}) .{ }^{1} \mathrm{H}$ NMR $\left(600 \mathrm{MHz}, \mathrm{CDCl}_{3}\right) \delta 7.02-6.91(\mathrm{~m}, 2 \mathrm{H}), 6.58-6.51(\mathrm{~m}, 2 \mathrm{H}), 4.14(\mathrm{qd}, J=7.5$, $2.3 \mathrm{~Hz}, 2 \mathrm{H}), 3.85(\mathrm{~s}, 1 \mathrm{H}), 3.41(\mathrm{td}, J=6.4,1.0 \mathrm{~Hz}, 2 \mathrm{H}), 2.58(\mathrm{td}, J=6.4,0.8 \mathrm{~Hz}, 2 \mathrm{H}), 2.23(\mathrm{~d}, J=2.3 \mathrm{~Hz}$, $3 \mathrm{H}), 1.25$ (ddd, $J=7.1,4.5,1.8 \mathrm{~Hz}, 3 \mathrm{H}) .{ }^{13} \mathrm{C} \mathrm{NMR}\left(151 \mathrm{MHz}, \mathrm{CDCl}_{3}\right) \delta 172.44,145.32,129.96,129.78$, $126.92,113.30,60.56,60.52,39.83,33.92,20.37,20.19,14.19$.

3-(Pyridin-2-ylamino)-propionic acid ethyl ester (3s): The product was obtained as a grey solid in a yield of 33\% (0.15 g). MP: $46-48{ }^{\circ} \mathrm{C}$ [35]. ${ }^{1} \mathrm{H}$ NMR $\left(600 \mathrm{MHz}, \mathrm{CDCl}_{3}\right) \delta 8.08(\mathrm{dd}, J=4.8,0.9 \mathrm{~Hz}, 1 \mathrm{H}), 7.45-$ $7.31(\mathrm{~m}, 1 \mathrm{H}), 6.56(\mathrm{dd}, J=6.7,5.4 \mathrm{~Hz}, 1 \mathrm{H}), 6.40(\mathrm{~d}, J=8.4 \mathrm{~Hz}, 1 \mathrm{H}), 4.96(\mathrm{~s}, 1 \mathrm{H}), 4.15(\mathrm{q}, J=7.1 \mathrm{~Hz}, 2 \mathrm{H})$, $3.64(\mathrm{~d}, J=5.1 \mathrm{~Hz}, 2 \mathrm{H}), 2.63(\mathrm{t}, J=6.2 \mathrm{~Hz}, 2 \mathrm{H}), 1.26(\mathrm{t}, J=7.1 \mathrm{~Hz}, 3 \mathrm{H}) .{ }^{13} \mathrm{C} \mathrm{NMR}\left(151 \mathrm{MHz}, \mathrm{CDCl}_{3}\right) \delta$ $172.61,158.22,147.93,137.37,112.94,107.64,60.60,37.36,34.23,14.20$.

3-p-Tolylamino-propionic acid tert-butyl ester (3t): The product was obtained as a yellow liquid in a yield of $82 \%(0.44 \mathrm{~g}) .{ }^{1} \mathrm{H}$ NMR $\left(600 \mathrm{MHz}, \mathrm{CDCl}_{3}\right) 86.91(\mathrm{~d}, J=7.9 \mathrm{~Hz}, 2 \mathrm{H}), 6.48(\mathrm{~d}, J=8.2 \mathrm{~Hz}, 2 \mathrm{H}), 3.83$ $(\mathrm{s}, 1 \mathrm{H}), 3.29(\mathrm{t}, J=6.3 \mathrm{~Hz}, 2 \mathrm{H}), 2.43(\mathrm{t}, J=6.3 \mathrm{~Hz}, 2 \mathrm{H}), 2.16(\mathrm{~s}, 3 \mathrm{H}), 1.37(\mathrm{~s}, 9 \mathrm{H}) .{ }^{13} \mathrm{C} \mathrm{NMR}(151 \mathrm{MHz}$, $\left.\mathrm{CDCl}_{3}\right) \delta 170.79,144.49,128.74,125.82,112.29,79.75,39.02,34.08,28.67,27.09,26.95,19.35$.

3-Phenylamino-propionic acid tert-butyl ester (3u) [36]: The product was obtained as a yellow liquid in a yield of $80 \%(0.37 \mathrm{~g}) .{ }^{1} \mathrm{H}$ NMR $\left(600 \mathrm{MHz}, \mathrm{CDCl}_{3}\right) \delta 7.16(\mathrm{dd}, J=11.1,4.2 \mathrm{~Hz}, 2 \mathrm{H}), 6.69(\mathrm{t}, J=7.3 \mathrm{~Hz}$, $1 \mathrm{H}), 6.60(\mathrm{~d}, J=7.9 \mathrm{~Hz}, 2 \mathrm{H}), 4.03(\mathrm{~s}, 1 \mathrm{H}), 3.37(\mathrm{t}, J=6.3 \mathrm{~Hz}, 2 \mathrm{H}), 2.50(\mathrm{t}, J=6.3 \mathrm{~Hz}, 2 \mathrm{H}), 1.44(\mathrm{~s}, 9 \mathrm{H})$. ${ }^{13} \mathrm{C}$ NMR $\left(151 \mathrm{MHz}, \mathrm{CDCl}_{3}\right) \delta 171.79,147.88,129.33,129.30,117.62,117.59,113.10,113.07,80.86,39.69$, $35.17,28.17,28.14$.

3-(4-Chloro-phenylamino)-propionic acid tert-butyl ester (3v): The product was obtained as a white solid in a yield of $83 \%(0.53 \mathrm{~g})$. MP: $33-36{ }^{\circ} \mathrm{C} .{ }^{1} \mathrm{H}$ NMR $\left(600 \mathrm{MHz}, \mathrm{CDCl}_{3}\right) \delta 7.13(\mathrm{~d}, J=8.7 \mathrm{~Hz}, 2 \mathrm{H}), 6.57(\mathrm{~d}, J=$ $8.7 \mathrm{~Hz}, 2 \mathrm{H}), 4.41(\mathrm{~s}, 1 \mathrm{H}), 3.37(\mathrm{t}, J=6.3 \mathrm{~Hz}, 2 \mathrm{H}), 2.52(\mathrm{t}, J=6.3 \mathrm{~Hz}, 2 \mathrm{H}), 1.45(\mathrm{~s}, 9 \mathrm{H}) .{ }^{13} \mathrm{C}$ NMR $(151$ $\left.\mathrm{MHz}, \mathrm{CDCl}_{3}\right) \delta 171.60,146.03,129.13,122.51,114.40,81.07,39.98,34.76,28.11$.

3-(Methyl-phenyl-amino)-propionamide (3w): The product was obtained as a white solid in a yield of $80 \%$ (0.43 g). MP: 88-90 ${ }^{\circ} \mathrm{C} .{ }^{1} \mathrm{H}$ NMR (600 MHz, DMSO-d6) $\delta 7.38(\mathrm{~s}, 1 \mathrm{H}), 7.21-7.10(\mathrm{~m}, 2 \mathrm{H}), 6.85(\mathrm{~s}, 1 \mathrm{H})$, $6.70(\mathrm{~d}, J=8.0 \mathrm{~Hz}, 2 \mathrm{H}), 6.65-6.54(\mathrm{~m}, 1 \mathrm{H}), 3.56-3.49(\mathrm{~m}, 2 \mathrm{H}), 2.84(\mathrm{~s}, 3 \mathrm{H}), 2.29-2.09(\mathrm{~m}, 2 \mathrm{H}) .{ }^{13} \mathrm{C}$ NMR (151 MHz, DMSO-d6) 8 173.82, 149.12, 129.54, 116.60, 116.13, 112.78, 112.43, 48.84, 38.13, 32.50.

3-(pyrrolidin-1-yl)propanamide (3x) [37]: The product was obtained as a yellow liquid in a yield of $96 \%$ $(0.48 \mathrm{~g}) .{ }^{1} \mathrm{H}$ NMR $\left(600 \mathrm{MHz}, \mathrm{CDCl}_{3}\right) \delta 8.21(\mathrm{~s}, 1 \mathrm{H}), 5.88(\mathrm{~s}, 1 \mathrm{H}), 2.79(\mathrm{~s}, 2 \mathrm{H}), 2.62(\mathrm{~s}, 4 \mathrm{H}), 2.45(\mathrm{~s}, 2 \mathrm{H})$, $1.82(\mathrm{t}, J=3.5 \mathrm{~Hz}, 4 \mathrm{H}) .{ }^{13} \mathrm{C}$ NMR $\left(151 \mathrm{MHz}, \mathrm{CDCl}_{3}\right) \delta 175.51,53.84,53.43,51.62,34.13,23.50,22.75$.

3-(4-methylpiperidin-1-yl)propanamide (3y): The product was obtained as a white solid in a yield of $95 \%$ (0.47 g). MP: $116-117^{\circ} \mathrm{C}[38] .{ }^{1} \mathrm{H}$ NMR $\left(600 \mathrm{MHz}, \mathrm{CDCl}_{3}\right) \delta 8.24(\mathrm{~s}, 1 \mathrm{H}), 5.43(\mathrm{~s}, 1 \mathrm{H}), 2.93(\mathrm{~d}, J=11.7$, $2 \mathrm{H}), 2.61(\mathrm{td}, J=6.4,3.8,2 \mathrm{H}), 2.40(\mathrm{t}, J=6.2,2 \mathrm{H}), 2.00(\mathrm{t}, J=11.0,2 \mathrm{H}), 1.68-1.56(\mathrm{~m}, 2 \mathrm{H}), 1.48-1.30(\mathrm{~m}$, $1 \mathrm{H}), 1.21(\mathrm{ddd}, J=15.6,12.5,3.7,2 \mathrm{H}), 0.88(\mathrm{~d}, J=6.5,3 \mathrm{H}) .{ }^{13} \mathrm{C} \mathrm{NMR}\left(151 \mathrm{MHz}, \mathrm{CDCl}_{3}\right) \delta 174.94,53.92$, $53.27,42.62,37.18,33.88,31.92,30.49,21.63$.

Phenylamine (1a) [39]: The product was obtained as a colorless liquid in a yield of $63 \%(0.12 \mathrm{~g}) .{ }^{1} \mathrm{H}$ $\operatorname{NMR}\left(600 \mathrm{MHz}, \mathrm{CDCl}_{3}\right) \delta 7.11(\mathrm{dd}, J=8.4,7.4 \mathrm{~Hz}, 2 \mathrm{H}), 6.72(\mathrm{t}, J=7.4 \mathrm{~Hz}, 1 \mathrm{H}), 6.58(\mathrm{dd}, J=8.5,1.0 \mathrm{~Hz}$, 2H), 3.49 (s, 2H). ${ }^{13} \mathrm{C}$ NMR (151 MHz, $\left.\mathrm{CDCl}_{3}\right) \delta 146.69,129.47,118.61,115.29$.

o-phenylenediamine (1b): The product was obtained as a colorless solid in a yield of $82 \%(0.17 \mathrm{~g})$. MP: 100-102 ${ }^{\circ} \mathrm{C}[40] .{ }^{1} \mathrm{H}$ NMR $\left(600 \mathrm{MHz}, \mathrm{CDCl}_{3}\right) \delta 6.87-6.50(\mathrm{~m}, 4 \mathrm{H}), 3.35(\mathrm{~s}, 4 \mathrm{H}) .{ }^{13} \mathrm{C} \mathrm{NMR}(151 \mathrm{MHz}$, $\left.\mathrm{CDCl}_{3}\right) \delta 134.71,120.22,116.70$.

1-Aminonaphthalene (1c): The product was obtained as a white solid in a yield of $85 \%(0.2 \mathrm{~g})$. MP: $45-48{ }^{\circ} \mathrm{C}[41] .{ }^{1} \mathrm{H}$ NMR $\left(600 \mathrm{MHz}, \mathrm{CDCl}_{3}\right) \delta 7.79(\mathrm{tt}, J=7.0,4.2 \mathrm{~Hz}, 2 \mathrm{H}), 7.51-7.37(\mathrm{~m}, 2 \mathrm{H}), 7.37-7.24$ $(\mathrm{m}, 2 \mathrm{H}), 6.76(\mathrm{dd}, J=7.1,1.2 \mathrm{~Hz}, 1 \mathrm{H}), 4.12(\mathrm{~s}, 2 \mathrm{H}) .{ }^{13} \mathrm{C} \mathrm{NMR}\left(151 \mathrm{MHz}, \mathrm{CDCl}_{3}\right) \delta 142.10,134.43,128.59$, $126.38,125.89,124.90,123.69,120.83,119.02,109.72$. 
4-Methoxy-phenylamine (1d): The product was obtained as a brown solid in a yield of $72 \%(0.16 \mathrm{~g})$. MP: 56-59 ${ }^{\circ} \mathrm{C}[42] .{ }^{1} \mathrm{H}$ NMR $\left(600 \mathrm{MHz}, \mathrm{CDCl}_{3}\right) \delta 6.86-6.68(\mathrm{~m}, 2 \mathrm{H}), 6.68-6.57(\mathrm{~m}, 2 \mathrm{H}), 3.85-3.61(\mathrm{~m}, 3 \mathrm{H})$, $3.39(\mathrm{~s}, 2 \mathrm{H}) .{ }^{13} \mathrm{C}$ NMR $\left(151 \mathrm{MHz}, \mathrm{CDCl}_{3}\right) \delta 152.78,139.92,116.41,114.79,55.72$.

2-Chloro-phenylamine (1e) [43]: The product was obtained as a colorless liquid in a yield of $40 \%(0.09 \mathrm{~g})$. ${ }^{1} \mathrm{H}$ NMR $\left(600 \mathrm{MHz}, \mathrm{CDCl}_{3}\right) \delta 7.31-7.19(\mathrm{~m}, 1 \mathrm{H}), 7.04(\mathrm{dd}, J=10.2,4.2 \mathrm{~Hz}, 1 \mathrm{H}), 6.68(\mathrm{dd}, J=16.0$, $6.6 \mathrm{~Hz}, 2 \mathrm{H}), 4.00(\mathrm{~s}, 2 \mathrm{H}) .{ }^{13} \mathrm{C}$ NMR $\left(151 \mathrm{MHz}, \mathrm{CDCl}_{3}\right) \delta$ 143.12, 129.53, 127.82, 119.32, 119.12, 116.06.

4-Bromo-phenylamine (1f): The product was obtained as a grey solid in a yield of $70 \%(0.19 \mathrm{~g})$. MP: 59-62 ${ }^{\circ} \mathrm{C}[44] .{ }^{1} \mathrm{H}$ NMR $\left(600 \mathrm{MHz}, \mathrm{CDCl}_{3}\right) \delta 7.29-7.09(\mathrm{~m}, 2 \mathrm{H}), 6.61-6.42(\mathrm{~m}, 2 \mathrm{H}), 3.66(\mathrm{~d}, J=36.7 \mathrm{~Hz}$, 2H). ${ }^{13} \mathrm{C}$ NMR $\left(151 \mathrm{MHz}, \mathrm{CDCl}_{3}\right) \delta 145.41,131.95,116.68,110.09$.

Phenylamine (1g): The product was obtained as a colorless liquid in a yield of $73 \%(0.12 \mathrm{~g}) .{ }^{1} \mathrm{H}$ NMR $\left(600 \mathrm{MHz}, \mathrm{CDCl}_{3}\right) \delta 7.11(\mathrm{dd}, J=8.4,7.4 \mathrm{~Hz}, 2 \mathrm{H}), 6.72(\mathrm{t}, J=7.4 \mathrm{~Hz}, 1 \mathrm{H}), 6.58(\mathrm{dd}, J=8.5,1.0 \mathrm{~Hz}, 2 \mathrm{H})$, $3.49(\mathrm{~s}, 2 \mathrm{H}) .{ }^{13} \mathrm{C}$ NMR $\left(151 \mathrm{MHz}, \mathrm{CDCl}_{3}\right) \delta 146.69,129.47,118.61,115.29$.

4-Bromo-phenylamine (1h): The product was obtained as a grey solid in a yield of $70 \%(0.17 \mathrm{~g})$. MP: 59-62 ${ }^{\circ} \mathrm{C} .{ }^{1} \mathrm{H}$ NMR $\left(600 \mathrm{MHz}, \mathrm{CDCl}_{3}\right) \delta 7.29-7.09(\mathrm{~m}, 2 \mathrm{H}), 6.61-6.42(\mathrm{~m}, 2 \mathrm{H}), 3.66(\mathrm{~d}, J=36.7 \mathrm{~Hz}$, 2H). ${ }^{13} \mathrm{C}$ NMR $\left(151 \mathrm{MHz}, \mathrm{CDCl}_{3}\right) \delta 145.41,131.95,116.68,110.09$.

o-phenylenediamine (1i): The product was obtained as a colorless solid in a yield of $81 \%(0.19 \mathrm{~g})$. MP: 100-102 ${ }^{\circ} \mathrm{C} .{ }^{1} \mathrm{H}$ NMR $\left(600 \mathrm{MHz}, \mathrm{CDCl}_{3}\right) \delta 6.87-6.50(\mathrm{~m}, 4 \mathrm{H}), 3.35(\mathrm{~s}, 4 \mathrm{H}) .{ }^{13} \mathrm{C} \mathrm{NMR}\left(151 \mathrm{MHz}, \mathrm{CDCl}_{3}\right)$ $\delta 134.71,120.22,116.70$.

3-Chloro-phenylamine (1j) [45]: The product was obtained as a colorless liquid in a yield of $35 \%(0.09 \mathrm{~g})$. ${ }^{1} \mathrm{H} \mathrm{NMR}\left(600 \mathrm{MHz}, \mathrm{CDCl}_{3}\right) \delta 7.01(\mathrm{t}, J=8.0 \mathrm{~Hz}, 1 \mathrm{H}), 6.69(\mathrm{dd}, J=7.9,1.1 \mathrm{~Hz}, 1 \mathrm{H}), 6.59(\mathrm{t}, J=2.1 \mathrm{~Hz}$, $1 \mathrm{H}), 6.47(\mathrm{dd}, J=8.1,2.2 \mathrm{~Hz}, 1 \mathrm{H}), 3.65(\mathrm{~s}, 2 \mathrm{H}) .{ }^{13} \mathrm{C} \mathrm{NMR}\left(151 \mathrm{MHz}, \mathrm{CDCl}_{3}\right) \delta 147.85,134.82,130.47$, $118.42,114.97,113.36$.

p-Tolylamine (1k): The product was obtained as a colorless solid in a yield of $72 \%(0.17 \mathrm{~g})$. MP: $43-45^{\circ} \mathrm{C}[46] .{ }^{1} \mathrm{H}$ NMR $\left(600 \mathrm{MHz}, \mathrm{CDCl}_{3}\right) \delta 7.07-6.83(\mathrm{~m}, 2 \mathrm{H}), 6.58(\mathrm{~d}, J=8.0 \mathrm{~Hz}, 2 \mathrm{H}), 3.46(\mathrm{~s}, 2 \mathrm{H})$, $2.23(\mathrm{~s}, 3 \mathrm{H}) .{ }^{13} \mathrm{C}$ NMR $\left(151 \mathrm{MHz}, \mathrm{CDCl}_{3}\right) \delta 143.91,129.82,127.80,115.32,20.52$.

p-Tolylamine (11): The product was obtained as a colorless solid in a yield of $76 \%(0.18 \mathrm{~g})$. MP: $43-45^{\circ} \mathrm{C}$. ${ }^{1} \mathrm{H}$ NMR $\left(600 \mathrm{MHz}, \mathrm{CDCl}_{3}\right) \delta 7.07-6.83(\mathrm{~m}, 2 \mathrm{H}), 6.58(\mathrm{~d}, J=8.0 \mathrm{~Hz}, 2 \mathrm{H}), 3.46(\mathrm{~s}, 2 \mathrm{H}), 2.23(\mathrm{~s}, 3 \mathrm{H}) .{ }^{13} \mathrm{C}$ NMR $\left(151 \mathrm{MHz}, \mathrm{CDCl}_{3}\right) \delta 143.91,129.82,127.80,115.32,20.52$.

Phenylamine $(\mathbf{1 m})$ : The product was obtained as a colorless liquid in a yield of $72 \%(0.16 \mathrm{~g}) .{ }^{1} \mathrm{H}$ NMR $\left(600 \mathrm{MHz}, \mathrm{CDCl}_{3}\right) \delta 7.11(\mathrm{dd}, J=8.4,7.4 \mathrm{~Hz}, 2 \mathrm{H}), 6.72(\mathrm{t}, J=7.4 \mathrm{~Hz}, 1 \mathrm{H}), 6.58(\mathrm{dd}, J=8.5,1.0 \mathrm{~Hz}, 2 \mathrm{H})$, 3.49 (s, 2H). ${ }^{13} \mathrm{C}$ NMR $\left(151 \mathrm{MHz}, \mathrm{CDCl}_{3}\right) \delta 146.69,129.47,118.61,115.29$.

Chloro-phenylamine (10): The product was obtained as a white solid in a yield of $82 \%(0.21 \mathrm{~g})$. MP: 65-67 ${ }^{\circ} \mathrm{C}[47] .{ }^{1} \mathrm{H}$ NMR $\left(600 \mathrm{MHz}, \mathrm{CDCl}_{3}\right) \delta 7.09(\mathrm{~d}, J=8.6 \mathrm{~Hz}, 2 \mathrm{H}), 6.60(\mathrm{~d}, J=8.6 \mathrm{~Hz}, 2 \mathrm{H}), 3.64(\mathrm{~s}$, 2H). ${ }^{13} \mathrm{C}$ NMR $\left(151 \mathrm{MHz}, \mathrm{CDCl}_{3}\right) \delta 144.97,129.14,123.16,116.25$.

2,3,4,5-tetrahydro-1H-1,5-benzodiazepin-2-one (6a, $\mathbf{6 b}$ and $\mathbf{6 c})$ : The products were obtained as a tan solid in yields of $74 \%(0.24 \mathrm{~g}), 68 \%(0.22 \mathrm{~g})$ and $34 \%(0.17 \mathrm{~g})$, respectively. MP: $138-140{ }^{\circ} \mathrm{C}$ [48,49]. ${ }^{1} \mathrm{H}$ NMR $\left(600 \mathrm{MHz}, \mathrm{CDCl}_{3}\right) \delta 8.36(\mathrm{~s}, 1 \mathrm{H}), 6.96(\mathrm{t}, J=7.5 \mathrm{~Hz}, 1 \mathrm{H}), 6.90(\mathrm{~d}, J=7.8 \mathrm{~Hz}, 1 \mathrm{H}), 6.82(\mathrm{t}, J=7.5 \mathrm{~Hz}, 1 \mathrm{H})$, $6.74(\mathrm{~d}, J=7.9 \mathrm{~Hz}, 1 \mathrm{H}), 3.70-3.63(\mathrm{~m}, 2 \mathrm{H}), 2.80-2.69(\mathrm{~m}, 2 \mathrm{H}) .{ }^{13} \mathrm{C} \mathrm{NMR}\left(151 \mathrm{MHz}, \mathrm{CDCl}_{3}\right) \delta 174.06$, $138.75,126.36,125.36,122.19,120.57,119.89,45.55,36.19$.

4-Methyl-4,5-dihydro-1H-benzo[b][1,4]diazepin-2(3H)-one (6d): The product was obtained as a white solid in a yield of $93 \%(0.30 \mathrm{~g})$. MP: $182-184{ }^{\circ} \mathrm{C}[50,51] .{ }^{1} \mathrm{H} \mathrm{NMR}\left(600 \mathrm{MHz}, \mathrm{CDCl}_{3}\right) \delta 8.60(\mathrm{~s}, 1 \mathrm{H}), 7.01-6.97$ $(\mathrm{m}, 1 \mathrm{H}), 6.95(\mathrm{dd}, J=7.7,1.0,1 \mathrm{H}), 6.88(\mathrm{t}, J=7.5,1 \mathrm{H}), 6.78(\mathrm{~d}, J=7.8,1 \mathrm{H}), 4.03(\mathrm{dt}, 1 \mathrm{H}), 3.55(\mathrm{~s}, 1 \mathrm{H})$, $2.64(\mathrm{dd}, J=13.6,4.0,1 \mathrm{H}), 2.45(\mathrm{dd}, J=13.7,7.9,1 \mathrm{H}), 1.33(\mathrm{~d}, J=6.3,3 \mathrm{H}) .{ }^{13} \mathrm{C} \mathrm{NMR}\left(151 \mathrm{MHz}, \mathrm{CDCl}_{3}\right)$ $\delta 173.07,138.25,128.00,125.64,122.19,121.41,121.00,54.14,41.44,23.62$. 
7,8-difluoro-2-methyl-1,2,3,5-tetrahydro-1,5-benzodiazepin-4-one (6e): The product was obtained as a white solid in a yield of $90 \%$ (0.29 g). MP: $193.5-195{ }^{\circ} \mathrm{C} .{ }^{1} \mathrm{H}$ NMR $\left(600 \mathrm{MHz}, \mathrm{CDCl}_{3}\right) \delta 8.46(\mathrm{~s}, 1 \mathrm{H}), 6.82(\mathrm{dd}, J$ $=10.6,7.9,1 \mathrm{H}), 6.64(\mathrm{dd}, J=11.0,7.5,1 \mathrm{H}), 4.05(\mathrm{dd}, J=12.1,6.3,1 \mathrm{H}), 3.38(\mathrm{~s}, 1 \mathrm{H}), 2.63(\mathrm{dd}, J=13.5,4.5$, $1 \mathrm{H}), 2.40(\mathrm{dd}, J=13.5,7.6,1 \mathrm{H}), 1.72(\mathrm{~s}, 1 \mathrm{H}), 1.33(\mathrm{~d}, J=6.3,3 \mathrm{H}) .{ }^{13} \mathrm{C} \mathrm{NMR}\left(151 \mathrm{MHz}, \mathrm{CDCl}_{3}\right) \delta=172.99$, $148.33,148.24,146.69,146.60,145.90,145.84,144.30,144.21,134.80,124.80,111.04,110.91,109.69,109.56$, $55.07,40.76,23.43$.

2,3-dihydro-1,5-benzothiazepine-4(5H)-one (6f): The product was obtained as a brown solid in a yield of 34\% (0.11 g). Mp: 215-216 ${ }^{\circ} \mathrm{C}[52] .{ }^{1} \mathrm{H}$ NMR (600 MHz, $\left.\mathrm{CDCl}_{3}\right) \delta 8.55(\mathrm{~s}, 1 \mathrm{H}), 7.61(\mathrm{~d}, J=7.7,1 \mathrm{H}), 7.37$ $(\mathrm{td}, J=7.7,1.2,1 \mathrm{H}), 7.17(\mathrm{t}, J=7.6,1 \mathrm{H}), 7.14(\mathrm{~d}, J=7.8,1 \mathrm{H}), 3.46(\mathrm{t}, J=6.9,2 \mathrm{H}), 2.65(\mathrm{t}, J=6.9,2 \mathrm{H}) .{ }^{13} \mathrm{C}$ NMR $\left(151 \mathrm{MHz}, \mathrm{CDCl}_{3}\right) \delta 173.71,141.41,135.51,129.83,126.97,126.49,123.30,34.29,33.54$.

3-Methyl-2,3-dihydrobenzo[b][1,4]thiazepin-4(5H)-one (6g): The product was obtained as a white solid in a yield of $31 \%(0.10 \mathrm{~g}) . \mathrm{Mp}: 176-178{ }^{\circ} \mathrm{C}$ [53]. ${ }^{1} \mathrm{H} \mathrm{NMR}\left(600 \mathrm{MHz}, \mathrm{CDCl}_{3}\right) \delta 8.32(\mathrm{~s}, 1 \mathrm{H}), 7.60(\mathrm{~d}, J=7.6$, $1 \mathrm{H}), 7.36(\mathrm{t}, J=6.9,1 \mathrm{H}), 7.17(\mathrm{t}, J=8.2,1 \mathrm{H}), 7.13(\mathrm{~d}, J=7.8,1 \mathrm{H}), 3.49(\mathrm{dd}, J=11.3,6.0,1 \mathrm{H}), 3.05-2.98$ $(\mathrm{m}, 1 \mathrm{H}), 2.79(\mathrm{dt}, J=12.6,6.3,1 \mathrm{H}), 1.19(\mathrm{~d}, J=6.6,3 \mathrm{H}) .{ }^{13} \mathrm{C} \mathrm{NMR}\left(151 \mathrm{MHz}, \mathrm{CDCl}_{3}\right) \delta 175.74,141.12$, $135.15,129.72,127.72,126.46,123.47,41.51,36.33,15.47$.

Supplementary Materials: The following are available online at http://www.mdpi.com/1420-3049/24/23/4224/s1. Figures S1-S74: C-NMR and H-NMR spectra of the products.

Author Contributions: Conceptualization, Z.D., Q.T. and Y.L.; methodology, Z.D., Q.T.; software, S.S.; validation, W.L. and X.W.; formal analysis, D.L.; investigation, Y.Z.; resources, Z.L.; data curation, Q.T.; writing-original draft preparation, Z.D.; writing-review and editing, Y.L.; visualization, Y.L.; supervision, Z.L.; project administration, Q.T.; funding acquisition, J.Y.

Funding: This research was funded by Chongqing Science and Technology Commission Project of china, grant number "cstc2018jscx-msybx0294".

Conflicts of Interest: The authors declare that there is no conflict of interest.

\section{References}

1. Jianyong, Y.; Wen, L.; Zeshu, D. 一种咪唑盐酸盐催化氨基保护的方法. Patent CN110028422A, 17 July 2019. (In Chinese).

2. Spaulding, A.; Takrouri, K.; Mahalingam, P.; Cleary, D.C.; Cooper, H.D.; Zucchi, P.; Tear, W.; Koleva, B.; Beuning, P.J.; Hirsch, E.B.; et al. Compound design guidelines for evading the efflux and permeation barriers of Escherichia coli with the oxazolidinone class of antibacterials: Test case for a general approach to improving whole cell Gram-negative activity. Bioorg. Med. Chem. Lett. 2017, 27, 5310-5321. [CrossRef] [PubMed]

3. Yang, B.; Shi, L.Y.; Wu, J.J.; Fang, X.; Yang, X.Y.; Wu, F.H. Microwave-assisted expeditious synthesis of 5-fluoroalkyl-3-(aryl/alkyl)-oxazolidin-2-ones. Tetrahedron 2013, 69, 3331-3337. [CrossRef]

4. Pan, L.; Lei, D.Y.; Jin, L.; He, Y.; Yang, Q.Q. Promising Fungicides from Allelochemicals: Synthesis of Umbelliferone Derivatives and Their Structure (-) Activity Relationships. Molecules 2018, 23, 3002. [CrossRef] [PubMed]

5. Samadi, S.; Jadidi, K.; Khanmohammadi, B.; Tavakoli, N. Heterogenization of chiral mono oxazoline ligands by grafting onto mesoporous silica MCM-41 and their application in copper-catalyzed asymmetric allylic oxidation of cyclic olefins. J. Catal. 2016, 340, 344-353. [CrossRef]

6. Yang, E.G.; Mustafa, N.; Tan, E.C.; Poulsen, A.; Ramanujulu, P.M.; Chng, W.J.; Yen, J.J.; Dymock, B.W. Design and Synthesis of Janus Kinase 2 (JAK2) and Histone Deacetlyase (HDAC) Bispecific Inhibitors Based on Pacritinib and Evidence of Dual Pathway Inhibition in Hematological Cell Lines. J. Med. Chem. 2016, 59, 8233-8262. [CrossRef] [PubMed]

7. Kim, J.G.; Jang, D.O. Trifluoroacetylation of amines with trifluoroacetic acid in the presence of trichloroacetonitrile and triphenylphosphine. Tetrahedron Lett. 2010, 51, 683-685. [CrossRef]

8. Hana, K.J.; Kim, M. A simple and efficient method for trifluoroacetylation of arylamines using trifluoroacetic acid and triphosgene. Lett. Org. Chem. 2011, 8, 559-561. [CrossRef] 
9. Ohtaka, J.; Sakamoto, T.; Kikugawa, Y. A one-pot procedure for trifluoroacetylation of arylamines using trifluoroacetic acid as a trifluoroacetylating reagent. Tetrahedron Lett. 2009, 50, 1681-1683. [CrossRef]

10. Saitoh, T.; Shimada, C.; Takeiri, M.; Shiino, M.; Ohba, S.; Obata, R.; Ishikawa, Y.; Umezawa, K.; Nishiyama, S. A new NF-kB inhibitor based on the amino-epoxyquinol core of DHMEQ. Bioorg. Med. Chem. Lett. 2010, 20, 5638-5642. [CrossRef]

11. Dighe, S.N.; Jadhav, H.R. Microwave assisted mild, rapid, solvent-less, and catalyst-free chemoselective N-tert-butyloxycarbonylation of amines. Tetrahedron Lett. 2012, 53, 5803-5806. [CrossRef]

12. Di Gioia, M.L.; Gagliardi, A.; Leggio, A.; Leotta, V.; Romio, E.; Liguori, A. N-Urethane protection of amines and amino acids in an ionic liquid. RSC Adv. 2015, 5, 63407-63420. [CrossRef]

13. Belsito, E.L.; Marco, R.D.; Gioia, M.L.D.; Liguori, A.; Perri, F.; Viscomi, M.C. N -(4-Nitrophenylsulfonyl)and N-(Fluorenylmethoxycarbonyl)-N-ethyl Amino Acid Methyl Esters-A Practical Approach. Eur. J. Org. Chem. 2010, 4245-4252. [CrossRef]

14. De Marco, R.; Di Gioia, M.L.; Leggio, A.; Liguori, A.; Perri, F.; Siciliano, C.; Viscomi, M.C. A new non-natural arginine-like amino acid derivative with a sulfamoyl group in the side-chain. Amino Acids 2010, 38, 691-700. [CrossRef] [PubMed]

15. Nardi, M.; Cano, N.H.; De Nino, A.; Di Gioia, M.L.; Maiuolo, L.; Oliverio, M.; Santiago, A.; Sorrentino, D.; Procopio, A. An eco-friendly tandem tosylation/Ferrier N -glycosylation of amines catalyzed by $\operatorname{Er}(\mathrm{OTf})_{3}$ in 2-MeTHF. Tetrahedron Lett. 2017, 58, 1721-1726. [CrossRef]

16. Becerra-Figueroa, L.; Ojeda-Porras, A.; Gamba-Sanchez, D. Transamidation of carboxamides catalyzed by Fe(III) and water. J. Org. Chem. 2014, 79, 4544-4552. [CrossRef]

17. Dai-Il, J.; Tae-wonchoi, C.; Yun-Young, K.; In-Shik, K.; You-Mi, P.; Yong-Gyun, L.; Doo-Hee, J. Synthesis Of 1,5-Benzodiazepine Derivatives. Synth. Commun. 1999, 29, 1941-1951. [CrossRef]

18. Baraldi, P.G.; Ruggiero, E.; Tabrizi, M.A. New Synthesis of Diazepino[3,2,1-ij]quinoline and Pyrido[1,2,3-de]quinoxalines via Addition-Elimination Followed by Cycloacylation. J. Heterocycl. Chem. 2014, 51, 101-105. [CrossRef]

19. Tang, X.J.; Yan, Z.L.; Chen, W.L.; Gao, Y.R.; Mao, S.; Zhang, Y.L.; Wang, Y.Q. Aza-Michael reaction promoted by aqueous sodium carbonate solution. Tetrahedron Lett. 2013, 54, 2669-2673. [CrossRef]

20. Payra, S.; Saha, A.; Banerjee, S. On-water magnetic $\mathrm{NiFe}_{2} \mathrm{O}_{4}$ nanoparticle-catalyzed Michael additions of active methylene compounds, aromatic/aliphatic amines, alcohols and thiols to conjugated alkenes. RSC Adv. 2016, 6, 95951-95956. [CrossRef]

21. Dabiri, M.; Salehi, P.; Bahramnejad, M.; Baghbanzadeh, M. Ecofriendly and efficient procedure for hetero-Michael addition reactions with an acidic ionic liquid as catalyst and reaction medium. Mon. Chem. 2011, 143, 109-112. [CrossRef]

22. Vijender, M.; Kishore, P.; Satyanarayana, B. Cadmium chloride $\left(\mathrm{CdCl}_{2}\right)$ : An effificient catalyst for conjugate addition of amines to electron-poor alkenes. Synth. Commun. 2007, 37, 591-594. [CrossRef]

23. Duan, Z.; Xuan, X.; Li, T.; Yang, C.; Wu, Y. Cerium (IV) ammonium nitrate (CAN) catalyzed aza-Michael addition of amines to $\alpha, \beta$-unsaturated electrophiles. Tetrahedron Lett. 2006, 47, 5433-5436. [CrossRef]

24. Meshram, H.M.; Lakshindra, C.; Reddy, P.N.; Sadashiv, K.; Yadav, J.S. Zirconium(IV) chloride-mediated chemoselective conjugate addition of aliphatic amines to $\alpha, \beta$-ethylenic compounds. Synth. Commun. 2006, 36, 795-801. [CrossRef]

25. Saidi, M.R.; Pourshojaei, Y.; Aryanasab, F. Highly Efficient Michael Addition Reaction of Amines Catalyzed by Silica-Supported Aluminum Chloride. Synth. Commun. 2009, 39, 1109-1119. [CrossRef]

26. Lin, Y.D.; Kao, J.Q.; Chen, C.T. Catalytic conjugate additions of nitrogen-, phosphorus-, and carbon-containing nucleophiles by amphoteric vanadyl triflate. Org. Lett. 2007, 9, 5195-5198. [CrossRef]

27. Yadav, J.S.; Ramesh Reddy, A.; Gopal Rao, Y.; Narsaiah, A.V.; Reddy, B.V.S. Lanthanum trichloride $\left(\mathrm{LaCl}_{3}\right)$ : An efficient catalyst for conjugate addition of amines to electron-deficient olefins. Lett. Org. Chem. 2007, 4, 462-464.

28. Nguyen, L.T.L.; Nguyen, T.T.; Nguyen, K.D.; Phan, N.T.S. Metal-organic framework MOF-199 as an efficient heterogeneous catalyst for aza-Michael reaction. Appl. Catal. A Gen. 2012, 425-426, 44-52. [CrossRef]

29. Ai, X.; Wang, X.; Liu, J.; Ge, Z.; Cheng, T.; Li, R. An effective aza-Michael addition of aromatic amines to electron-deficient alkenes in alkaline $\mathrm{Al}_{2} \mathrm{O}_{3}$. Tetrahedron 2010, 66, 5373-5377. [CrossRef] 
30. Takamura, K.; Shioya, A.; Minamoto, K.; Asada, N.; Takaku, S.; Yoshimitsu, A.; Nitta, Y. Studies on analgesics of aniline series. I. Preparation and properties of beta-alaninamide series. Chem. Pharm. Bull. 1965, 13, 198-204. [CrossRef]

31. Bosica, G.; Abdilla, R. Aza-Michael Mono-addition Using Acidic Alumina under Solventless Conditions. Molecules 2016, 21, 815. [CrossRef]

32. You, L.; Song, F.; Rui, A.; Wang, X.; Bai, D. ChemInform Abstract: Silica Gel Accelerated Aza-Michael Addition of Amines to $\alpha, \beta$-Unsaturated Amides. Tetrahedron Lett. 2008, 49, 5147-5149. [CrossRef]

33. Rostamnia, S.; Alamgholiloo, H. Synthesis and Catalytic Application of Mixed Valence Iron (FeII/FeIII)-Based OMS-MIL-100(Fe) as an Efficient Green Catalyst for the aza-Michael Reaction. Catal. Lett. 2018, 148, 2918-2928. [CrossRef]

34. Neogi, S.; Naskar, D. ChemInform Abstract: One-Pot Reductive Mono-N-Alkylation of Aromatic Nitro Compounds Using Nitriles as Alkylating Reagents. Synth. Commun. 2011, 41, 1901-1915. [CrossRef]

35. Xu, W.Q.; Ren, Y.J.; Wang, Q.W.; Sun, Y.X. Triflic Acid as Efficient Catalyst for the Hydroamination of Ethyl Acrylate with 2-Aminopyridines. Lett. Org. Chem. 2015, 12, 146-152. [CrossRef] [PubMed]

36. Laursen, J.S.; Engel-Andreasen, J.; Fristrup, P.; Harris, P.; Olsen, C.A. Cis-trans amide bond rotamers in beta-peptoids and peptoids: Evaluation of stereoelectronic effects in backbone and side chains. J. Am. Chem. Soc. 2013, 135, 2835-2844. [CrossRef]

37. Ying, A.; Li, Z.; Yang, J.; Liu, S.; Xu, S.; Yan, H.; Wu, C. DABCO-based ionic liquids: Recyclable catalysts for aza-Michael addition of $\alpha, \beta$-unsaturated Amides under Solvent-Free Conditions. J. Org. Chem. 2014, 79, 6510-6516. [CrossRef] [PubMed]

38. Yang, P.; Liu, Y.; Ling, C.; Lai, Z.; Fang, X.; Liu, B.; Zhang, W.; Lu, M.; Xu, Y.; Hao, X. Nmp-based ionic liquids: Recyclable catalysts for both hetero-Michael addition and Knoevenagel condensation in water. Synth. Commun. 2018, 48, 1060-1067. [CrossRef]

39. Kreye, O.; Wald, S.; Meier, M.A.R. ChemInform Abstract: Introducing Catalytic Lossen Rearrangements: Sustainable Access to Carbamates and Amines. Adv. Synth. Catal. 2013, 355, 81-86. [CrossRef]

40. Cantillo, D.; Baghbanzadeh, M.; Kappe, C.O. In situ generated iron oxide nanocrystals as efficient and selective catalysts for the reduction of nitroarenes using a continuous flow method. Angew. Chem. Int. Ed. 2012, 51, 10190-10193. [CrossRef]

41. Ji, P.; Manna, K.; Lin, Z.; Feng, X.; Urban, A.; Song, Y.; Lin, W. Single-Site Cobalt Catalysts at New $\mathrm{Zr}_{12}\left(\mu_{3}-\mathrm{O}_{8}\left(\mu_{3}-\mathrm{OH}\right)_{8}\left(\mu_{2}-\mathrm{OH}\right)_{6}\right.$ Metal-Organic Framework Nodes for Highly Active Hydrogenation of Nitroarenes, Nitriles, and Isocyanides. J. Am. Chem. Soc. 2017, 139, 7004-7011. [CrossRef]

42. Ding, Z.C.; Li, C.Y.; Chen, J.J.; Zeng, J.H.; Tang, H.T.; Ding, Y.J.; Zhan, Z.P. Palladium/Phosphorus-Doped Porous Organic Polymer as Recyclable Chemoselective and Efficient Hydrogenation Catalyst under Ambient Conditions. Adv. Synth. Catal. 2017, 359, 2280-2287. [CrossRef]

43. Cohen, S.; Bilyachenko, A.N.; Gelman, D. Bifunctional Pincer Catalysts for Chemoselective Transfer Hydrogenation and Related Reactions. Eur. J. Inorg. Chem. 2019, 2019, 3203-3209. [CrossRef]

44. Gayakwad, E.M.; Patel, K.P.; Shankarling, G.S. Sodium sulfate-hydrogen peroxide-sodium chloride adduct: Selective protocol for the oxidative bromination, iodination and temperature dependent oxidation of sulfides to sulfoxides and sulfones. New J. Chem. 2019, 43, 6001-6009. [CrossRef]

45. Duan, Z.; Ma, G.; Zhang, W. Preparation of Copper Nanoparticles and Catalytic Properties for the Reduction of Aromatic Nitro Compounds. Bull. Korean Chem. Soc. 2012, 33, 4003-4006. [CrossRef]

46. Portada, T.; Margetic, D.; Strukil, V. Mechanochemical Catalytic Transfer Hydrogenation of Aromatic Nitro Derivatives. Molecules 2018, 23, 3163. [CrossRef]

47. Jiang, Z.; Wu, Z.; Wang, L.; Wu, D.; Zhou, X. Preparation of aromatic amines by copper-catalyzed coupling of boronic acids with aqueous ammonia. Can. J. Chem. 2010, 88, 964-968. [CrossRef]

48. Doebelin, C.; Schmitt, M.; Antheaume, C.; Bourguignon, J.J.; Bihel, F. Nucleophilic Substitutionof Azide Acting as a Pseudo Leaving Group: One-Step Synthesis of VariousAza Heterocycles. J. Org. Chem. 2013, 78, 11335-11341. [CrossRef]

49. Taylor, A.M.; Vaswani, R.G.; Gehling, V.S.; Hewitt, M.C.; Leblanc, Y.; Audia, J.E.; Bellon, S.; Cummings, R.T.; Cote, A.; Harmange, J.C.; et al. Discovery of Benzotriazolo[4,3-d][1,4]diazepines as orally active Inhibitors of BET bromodomains. ACS Med. Chem. Lett. 2015, 7, 145-150. [CrossRef]

50. Wang, X.; Li, Z.; Zhu, X.; Mao, H.; Zou, X.; Kong, L.; Li, X. Features and applications of reactions of $\alpha, \beta$-unsaturated -acylbenzotriazoles with amino compounds. Tetrahedron 2008, 64, 6510-6521. [CrossRef] 
51. Pan, Y.; Chen, C.; Xu, X.; Zhao, H.; Han, J.; Li, H.; Xu, L.; Fan, Q.; Xiao, J. Metal-free tandem cyclization/hydrosilylation to construct tetrahydroquinoxalines. Green Chem. 2018, 20, 403-411. [CrossRef]

52. Nageswara Rao, S.; Chandra Mohan, D.; Adimurthy, S. ChemInform Abstract: Chitosan: An Efficient Recyclable Catalyst for Transamidation of Carboxamides with Amines under Neat Conditions. Green Chem. 2014, 16, 4122-4126. [CrossRef]

53. Rana, N.K.; Singh, V.K. ChemInform Abstract: Enantioselective Enolate Protonation in Sulfa-Michael Addition to $\alpha$-Substituted N-Acryloyloxazolidin-2-ones with Bifunctional Organocatalyst. Org. Lett. 2011, 13, 6520-6523. [CrossRef] [PubMed]

(C) 2019 by the authors. Licensee MDPI, Basel, Switzerland. This article is an open access article distributed under the terms and conditions of the Creative Commons Attribution (CC BY) license (http://creativecommons.org/licenses/by/4.0/). 